\title{
First Report On The Occurrence of Pharmaceuticals And Cocaine In The Coastal Waters of Santa Catarina, Brazil, And Its Related Ecological Risk Assessment
}

\author{
Ane-Mery Pisetta \\ Universidade Fernando Pessoa \\ Vinicius Roveri \\ UNIMES: Universidade Metropolitana de Santos \\ Luciana Lopes Guimarães \\ UNISANTA: Universidade Santa Cecilia \\ Therezinha Maria Novais de Oliveira \\ Universidade da Regiao de Joinville \\ Alberto Teodorico Correia ( $\nabla$ atcorreia.ciimar@gmail.com ) \\ Universidade do Porto Centro Interdisciplinar de Investigacao Marinha e Ambiental \\ https://orcid.org/0000-0002-2831-025X
}

\section{Research Article}

Keywords: Subtropical ecosystem, Ocean discharge, Pharmaceuticals, Illicit drugs, Pollution effects, Risk assessment

Posted Date: December 20th, 2021

DOI: https://doi.org/10.21203/rs.3.rs-1123933/v1

License: (c) (i) This work is licensed under a Creative Commons Attribution 4.0 International License. Read Full License

Version of Record: A version of this preprint was published at Environmental Science and Pollution Research on April 22nd, 2022. See the published version at https://doi.org/10.1007/s11356-022-20312-z. 


\section{Abstract}

The worldwide occurrence of pharmaceuticals and personal care products (PPCPs) in aquatic ecosystems is reason for concern, since these emerging micro pollutants, includes a large and diverse group of organic compounds, with continuous input, high environmental persistence and potential threat to biota and human health. The aim of this study was to evaluate, for the first time, the occurrence of twenty-seven PPCPs of various therapeutic classes (including cocaine and its primary metabolite, benzoylecgonine), in the coastal waters of Santa Catarina, southern Brazil. Water samples were taken in November 2020, during the low tide periods, at eight sampling points located along the coast of Santa Catarina, covering its entire geographical extension. Sampling was carried out in triplicate and at different depths of the water column. Nine compounds were detected through liquid chromatography coupled with tandem mass spectrometry (LC-MS/MS): caffeine (12.58-119.80 ng/L), diclofenac (1.398-7.920 ng/L), losartan (0.432-3.200 ng/L), cocaine (0.0248-0.1686 ng/L) and benzoylecgonine (0.0146-1.094 ng/L) were quantified in $100 \%$ of the samples; carbamazepine $(0.0242-0.2720 \mathrm{ng} / \mathrm{L})$ was quantified in $75 \%$ of the samples; acetaminophen $(0.212-10.040 \mathrm{ng} / \mathrm{L})$ was quantified in $60 \%$ of the samples; and both atenolol (1.13-2.50 $\mathrm{ng} / \mathrm{L}$ ) and orphenadrine (0.073-0.0886 $\mathrm{ng} / \mathrm{L})$ were quantified in $25 \%$ of the samples. The other PPCPs were below the limit of detection (LOD). The highest occurrence of these compounds was detected in the northern and central coastal region of Santa Catarina, namely in Penha and Palhoça cities. The sources of these compounds may be associated with areas with high population density, awaited by tourism, with consequent production of sanitary sewage and solid waste. The ecological risk assessment of these substances in the aquatic ecosystems showed that $67 \%$ and $77 \%$ of the compounds respectively presented no ecological risk, acute and chronic, but $44 \%$ presented low to moderate risks for acute and chronic effects in the three trophic levels evaluated. The occurrence of these chemical compounds can imply deleterious effects on the environmental health of Santa Catarina coastal zone, and therefore deserve more acute and directed attention.

\section{Introduction}

Pharmaceutical drugs prescribed to diagnose, treat or prevent diseases in humans and animals, are physiologically metabolized and eliminated through urine and faeces, in the form of the parental compound or of its metabolites, being later discarded into the aquatic environment through household sewage (Sirbu et al., 2006; Costa Junior et al., 2014; Ekpeghere et al., 2018). Moreover, consumption practices such as the self-medication, the excessive and indiscriminate use of drugs, the medicine freetrade, and the direct disposal of pharmaceuticals explain the worldwide occurrence of these chemical compounds in the environment (Ortiz de García et al., 2013; Pereira et al., 2017; Freitas and RadisBaptista, 2021). Thus, the United Nations (UN) proposed the rational use of medicines, so that these are administered in doses that meet individual needs and for a suitable period, reducing costs and, consequently, adverse impacts on the environment and human health (Daughton, 2007; WHO, 2021). The adverse and harmful effects of PPCPs on the environment range from the spread of antimicrobial resistance and species survival even interference in the reproduction of aquatic organisms and increased 
incidence of cancer in humans (Overturf et al., 2015; Freitas and Radis-Baptista, 2021; Wang et al., 2021). There are several routes that lead the PPCPs to the environment and the knowledge of its occurrence, sources, fate and toxicity provides subsidies to establish minimization and control strategies (Daughton, 2007; Ebele et al., 2017).

The ineffectiveness of most wastewater treatment plants (WWTP) regarding the removal of pharmaceutical and personal care products (PPCPs) (Del Rosário et al., 2014; Wang and Wang, 2016; Ng et al., 2021), makes these compounds, partially or fully, discarded into receiving waters, which may cause deleterious effects to aquatic non-target organisms (e.g., algae crustaceans and fishes) (Baena-Nogueras et al., 2017; Diamanti et al., 2019; Fontes et al., 2019). Studies carried out in WWTP worldwide, namely in Finland (Vieno et al., 2007), Faroe Islands, Iceland and Greenland (Huber et al., 2016) and in other regions (Kim et al., 2012; Kosma et al., 2014; Kumar et al., 2019), demonstrated that some compounds are not totally eliminated by the conventional treatments, and that drug residues still remain in the treated effluent (Vieno et al., 2007; Gurke et al., 2015; Zhou et al., 2019). PPCPs can also return to the environment if the destination of the WWTP sludge is inappropriate (Alvarez-Ruiz et al., 2015; Sun et al., 2016; Ebele et al., 2017). Moreover, the use of surface waters that receives sanitary sewage or treated wastewater for irrigation purposes, as well as the use fertilizers made of WWTP sludge, promotes the introduction of PPCPs in the soil (Wu et al., 2015; Bartrons and Peñuelas, 2017; Madikizela et al., 2018). And thus, may cause risks to human health from exposure to contaminated food (Goldstein et al., 2014; Al-Farsi et al., 2018; Keerthanan et al., 2021), in addition to allowing the transport of PPCPs to water bodies (Sui et al., 2015; Ebele et al., 2017; Wilkinson et al., 2017). The movement of these pollutants through runoff to the aquatic environment promotes the accumulation of these substances in inland, estuarine and coastal waters (Stewart et al., 2014; Roveri et al., 2020a; 2021b). Furthermore, in the aquatic environment, PPCPs can undergo biotic and abiotic transformations generating other byproducts, besides the potential additive and synergistic effects with other drugs in complex mixtures (Evgenidou et al., 2014; Yuan et al., 2020; Hamid et al., 2021). As such, even in coastal waters of remote locations and theoretically pristine, like the Arctic Ocean and Antarctica, the occurrence of PPCPs associated with domestic sewage discharge and solid waste disposal was already detected (Emnet et al., 2015; Balakrishna et al., 2018; Kallenborn et al., 2018).

In the Brazil, including Santa Catarina state, most of the existing WWTPs, operate with conventional treatment processes (ANA, 2021; Heinz et al., 2021; Roveri et al., 2021b), not being, therefore, suitable for the total removal of the PPCPs (Behera et al., 2011; Wang and Wang, 2016; Kumar et al., 2019) which needs more advanced systems to achieve this efficiency (Yang et al., 2017; Tarpani and Azapagic, 2018; Rigueto et al., 2020). In addition, there is no regulation that sets specific limits for these compounds in effluents and/or environmental waters (i.e., fresh, salty or brackish waters) (Chiavelli et al., 2019; ANA, 2021; MMA, 2021). In the last decades, the studies dedicated to screen the occurrence of PPCPs in aquatic ecosystems off the Brazilian coast are scarce, mainly focused in São Paulo and Rio de Janeiro, limited to a few therapeutic classes and mostly published in national journals and reports (Quadra et al., 2017). A few examples can be find here: one of the first published reports was related to the occurrence of PPCPs in the marine sediments of Todos os Santos Bay, Bahia, Brazil (Beretta et al., 2014). In Santos 
city, São Paulo coastline, cocaine and benzoylecgonine were monitored near the discharge of the submarine outfall in the Santos Bay (Fontes et al., 2019). Recently, a few works were published concerning the coastal area of São Paulo, Brazil: 16 PPCPs were detected in the urban drainage channels flowing into the bathing waters of Guarujá (Roveri et al., 2020a); 10 PPCPs were found near on the discharge of submarine outfall in the Enseada beach, Guarujá (Roveri et al., 2021a); and 21 PPCPs were recorded in the urban drainage channels that flow to Santos city (Roveri et al., 2021b). However, despite the existence of several agricultural and industrial activities potentially generating PPCPs in the coastal region of Santa Catarina, there are no studies on the occurrence and ecological risk of PPCPs in this densely populated coastal area.

The aim of this study was to evaluate, for the first time, the presence of twenty-seven PPCPs of various therapeutic classes (including cocaine and its primary metabolite, benzoylecgonine) along the coast of the state of Santa Catarina, Brazil, in water samples collected under the influence of the major estuaries. Simultaneously, an ecological risk assessment of the measured maximum concentrations of the different PPCPs in the aquatic biota was carried out. The information obtained here will allow to construct a database on the influence of emerging pollutants on the aquatic ecosystem of the Santa Catarina coast, serving as a support for future decisions by public authorities regarding the use, occupation and management of these coastal areas, particularly for areas with intense human occupation.

\section{Materials And Methods}

\subsection{Study site description}

The present study took place in the coastal area of Santa Catarina (SC) state, south Brazil. SC has an area of $95,730.684 \mathrm{~km}^{2}$ with a population of 6,218.436 (Ibge, 2010), and is composed of 295 municipalities politically divided into eight regions (Ibge, 2020). SC is delimited by two drainage systems, the Sistema Integrado da Vertente do Interior (SIVI) and the Sistema da Vertente Atlântica (SVA). SVA covers approximately $36,354 \mathrm{~km}^{2}$, which represents $38 \%$ of the total area of the state, and also concentrate a large part of the population of the state, around $41 \%$, since the four biggest cities are located in or near the coastal area, namely Joinville (515,288 population), Florianópolis, Capital of Santa Catarina (421,240 population), Blumenau (309,011 population) and Criciúma (192,308 population) (Filho, 2003; SDE, 2020; ANA, 2021). The SVA is composed of five hydrographic regions (HR) [North coast (HR6), Itajaí Valley (HR7), Coast center (HR8), Southern SC (HR9) and Extreme South of SC (HR10)], which drain their waters to the SC coastline (Figure 1), which is $561 \mathrm{~km}$ long (Ibge, 2020). The present sampling design included the eight major estuaries, distributed from North to South, on the coast of SC, located in regions that are influenced by the main rivers and the largest cities of the state, and with different anthropogenic contamination profiles (Table 1). The characterization of the anthropogenic profile of each sampling site was carried out based on the data bases of the State Secretariat for Sustainable Development (SEBRAE, 2013) and of the Industries Federation Observatory of the State of Santa Catarina (FIESC) (FIESC, 2021). 
Table 1

Location, geographic coordinates and main anthropogenic contributions for each sampling point.

\begin{tabular}{|c|c|c|c|}
\hline $\begin{array}{l}\text { Sampling } \\
\text { Point }\end{array}$ & Location & Coordinates & $\begin{array}{l}\text { Predominant } \\
\text { anthropogenic } \\
\text { contribution* }\end{array}$ \\
\hline \multirow[t]{3}{*}{1} & North coast & $\begin{array}{l}\text { Lat.: } \\
26^{\circ} 09^{\prime} 49.34^{\prime \prime} S\end{array}$ & $\begin{array}{l}\text { Metalworking and metal- } \\
\text { mechanic Industry }\end{array}$ \\
\hline & \multirow[t]{2}{*}{$\begin{array}{l}\text { São Francisco do Sul - Enseada / } \\
\text { Costão do Forte Marechal Luz }\end{array}$} & $\begin{array}{l}\text { Long.: } \\
48^{\circ} 31^{\prime} 58.14^{\prime \prime} 0\end{array}$ & $\begin{array}{l}\text { Sanitary/Industrial } \\
\text { landfill }\end{array}$ \\
\hline & & & Agriculture: Rice farming \\
\hline \multirow[t]{3}{*}{2} & North coast & $\begin{array}{l}\text { Lat: } \\
26^{\circ} 27^{\prime} 11.51^{\prime \prime S}\end{array}$ & $\begin{array}{l}\text { Furniture and metal- } \\
\text { mechanic industry }\end{array}$ \\
\hline & \multirow[t]{2}{*}{$\begin{array}{l}\text { Balneário Barra do Sul - Molhe do Canal } \\
\text { do Linguado }\end{array}$} & $\begin{array}{l}\text { Long.: } \\
48^{\circ} 35^{\prime} 38.05^{\prime \prime} \mathrm{O}\end{array}$ & $\begin{array}{l}\text { Sanitary/industrial } \\
\text { landfill }\end{array}$ \\
\hline & & & Agriculture: Rice farming \\
\hline \multirow[t]{3}{*}{3} & & \multirow{3}{*}{$\begin{array}{l}\text { Lat.: } \\
26^{\circ} 47^{\prime} 23.01^{\prime \prime} \mathrm{S} \\
\text { Long.: } \\
48^{\circ} 36^{\prime} 24.74^{\prime \prime} 0\end{array}$} & Textile industry \\
\hline & \multirow[t]{2}{*}{$\begin{array}{l}\text { Penha - Rua Inácio F. De Souza - Praia } \\
\text { da Armação do Itapocorói }\end{array}$} & & $\begin{array}{l}\text { Sanitary/Industrial } \\
\text { landfill }\end{array}$ \\
\hline & & & Agriculture: Rice farming \\
\hline \multirow[t]{2}{*}{4} & Central-North coast & $\begin{array}{l}\text { Lat.: } \\
27^{\circ} 10^{\prime} 59.15^{\prime \prime} \mathrm{S}\end{array}$ & Ceramic Industry \\
\hline & Porto Belo - Praia de Zimbros & $\begin{array}{l}\text { Long.: } \\
48^{\circ} 32^{\prime} 33.84^{\prime \prime} 0\end{array}$ & $\begin{array}{l}\text { Sanitary/Industrial } \\
\text { Landfill }\end{array}$ \\
\hline \multirow[t]{2}{*}{5} & Central coast & $\begin{array}{l}\text { Lat.: } \\
27^{\circ} 47^{\prime} 37.78^{\prime \prime} S\end{array}$ & $\begin{array}{l}\text { Landfill/Industrial } \\
\text { Landfill }\end{array}$ \\
\hline & Palhoça - Enseada do Brito & $\begin{array}{l}\text { Long.: } \\
48^{\circ} 37^{\prime} 52.88^{\prime \prime} 0\end{array}$ & Energy and Tourism \\
\hline \multirow[t]{2}{*}{6} & Central-South coast & $\begin{array}{l}\text { Lat:: } \\
28^{\circ} 11^{\prime} 34.13^{\prime \prime} \mathrm{S}\end{array}$ & $\begin{array}{l}\text { Mechanical/Metallurgical } \\
\text { Industry }\end{array}$ \\
\hline & $\begin{array}{l}\text { Imbituba - Praia de Ibiraquera - } \\
\text { Ribanceira }\end{array}$ & $\begin{array}{l}\text { Long.: } \\
48^{\circ} 39^{\prime} 34.18^{\prime \prime} 0\end{array}$ & $\begin{array}{l}\text { Sanitary/Industrial } \\
\text { Landfill }\end{array}$ \\
\hline \multirow[t]{2}{*}{7} & Central-South coast & $\begin{array}{l}\text { Lat.: } \\
28^{\circ} 29^{\prime} 39.20^{\prime \prime} \mathrm{S}\end{array}$ & Chemical Industry \\
\hline & Laguna - Molhe & $\begin{array}{l}\text { Long.: } \\
48^{\circ} 45^{\prime} 0.38^{\prime \prime} 0\end{array}$ & $\begin{array}{l}\text { Sanitary/Industrial } \\
\text { Landfill }\end{array}$ \\
\hline
\end{tabular}

Source: * The authors based this information on data from SEBRAE $(2013)$ and FIESC $(2020,2021)$. 


\begin{tabular}{|llll|}
\hline $\begin{array}{l}\text { Sampling } \\
\text { Point }\end{array}$ & Location & Coordinates & $\begin{array}{l}\text { Predominant } \\
\text { anthropogenic } \\
\text { contribution* }\end{array}$ \\
\hline 8 & South coast & Lat.: & $\begin{array}{l}\text { Ceramic industry/Energy/ } \\
\text { chemical Industry }\end{array}$ \\
& $\begin{array}{l}\text { Içara - Balneário Rincão - Plataforma } \\
\text { da Pesca }\end{array}$ & $\begin{array}{l}\text { Long.: } \\
48^{\circ} 19^{\prime} 55.68^{\prime \prime} \mathrm{O}\end{array}$ & $\begin{array}{l}\text { Sanitary/Industrial } \\
\text { Landfill }\end{array}$ \\
\hline
\end{tabular}

Source: * The authors based this information on data from SEBRAE $(2013)$ and FIESC $(2020,2021)$.

\subsection{Collection of samples}

The study was carried out at eight sampling points (labelled as P), along the coast of SC. The Table 1 and Figure 1 presents (i) the details of the selected locations along SC coastline; (ii) the land use and occupation characteristics, and (iii) their geographic coordinates. The sampling points of the study area were chosen taking into consideration the coastal area under the influence of the largest rivers of the different hydrographic regions (labelled as HR) (SDE, 2020). The samples were collected during spring, on November 9th and 10th, 2020, during the day and at low tide. Water was stored in amber bottles, previously cleaned with water and detergent, rinsed with plenty of tap water, ending with solvent application, methanol and, final rinse with distilled water to eliminate any trace of possible contaminants. The water was collected in triplicate, carried out in three different heights, $30 \mathrm{~cm}, 60 \mathrm{~cm}$ and $90 \mathrm{~cm}$ from the surface. Equal volume aliquots $(500 \mathrm{~mL})$ were mixed and homogenized. From the final mixture an aliquot of $1 \mathrm{~L}$ was used. All samples were kept at $4^{\circ} \mathrm{C}$, and target PPCPs were extracted from water samples within four days of collection (ANA, 2011).

\subsection{Preparation and analysis of pharmaceutical compounds 2.3.1 Chemical and standards}

Chemicals and analytical reagents such as nitric acid and sulphuric acid were purchased from Merck (Darmstadt, Germany). Grade solvents used in HPLC and LC-MS, such as acetonitrile, methanol and isopropanol, were acquired from Sigma-Aldrich (Massachusetts, USA). Mobile phase additives, namely LC-MS grade formic acid and ammonium acetate, were acquired from Sigma-Aldrich and Merck, respectively. Analytical standards of acetaminophen, atenolol, bromazepam, caffeine, carbamazepine, cyproterone, clonazepam, clopidogrel, diclofenac, enalapril, loratadine, losartan, midazolam orphenadrine, propranolol, sildenafil, atorvastatin, ranitidine, diazepam, chlorpheniramine and valsartan were acquired from Sigma-Aldrich. Cocaine and benzoylecgonine were acquired from Cerillant (Texas, USA). The other pharmaceuticals were bought in several suppliers: citalopram (Alcytam $\AA$ : Torrent, Brazil), chlortalidone (Higroton $\AA^{\circledR}$ : Novartis, Swiss), rosuvastatin (Crestor ${ }^{\circledR}:$ AstraZeneca, UK) and generic paroxetine medication (Medley, Brazil).

\subsubsection{Sample preparation}


The extraction technique used in the hereby study was modified from Wille et al. (2010), and fully described by Roveri et al. (2021b). Prior to the extraction, the following procedures were adopted: (i) the $\mathrm{pH}$ of each sample was adjusted to $7.0 \pm 0.5$ using a hydrochloric acid solution ( $1 \mathrm{M})$; (ii) samples were filtered through a cellulose filter paper (Whatman ${ }^{\circledR}$ GF/C Glass microfiber filters, diameter $47 \mathrm{~mm}$, particle retention $1.2 \mu \mathrm{m}$; Merck, Darmstadt, German); (iii) the filters were washed with $2 \mathrm{~mL}$ of methanol (SigmaAldrich, St. Louis, USA); and (iv) at the end, the methanol extract collected wascombined to the filtered sample. The solid-phase extraction was performed using SPE Chromabond HR-X cartridges $(200 \mathrm{mg}, 3$ $\mathrm{mL}$; Marcherey-Nagel, Duren, Germany). The cartridges were preconditioned with methanol $(5 \mathrm{~mL})$ and ultrapure water ( $5 \mathrm{~mL}$ ) (Milli-Q®-Merck, Darmstadt, Germany). Thereafter, there were loaded with $1 \mathrm{~L}$ of the filtered sample combined with the methanol from filter washings. The cartridges were then dried under vacuum for $30 \mathrm{~min}$, and the elution was performed twice using $5 \mathrm{~mL}$ of methanol and $5 \mathrm{~mL}$ of acetone. After the extraction, the samples were dried under a nitrogen flow $\left(\right.$ at $\left.50^{\circ} \mathrm{C}\right)$ and eluted with water/acetonitrile (95:5 v/v) prior to mass spectrometry analysis. In the laboratory each water sample was analysed in triplicate using LC-MS-MS. A concentration factor $(1 / 1000)$ was used to obtain the final concentrations, and individual average results were expressed in $\mathrm{ng} / \mathrm{L}$ (Figures 2 and 3 ).

\subsubsection{LC-MS/MS analysis}

The hereby 27 PPCPs screened were selected taking into account the occurrence, reported annual consumption, expected toxicity and environmental persistence (Cmed, 2021; Roveri et al., 2021b). LCMS/MS analytical procedures were validated by Shihomatzu (2015) and fully described by Roveri et al. (2021b). Briefly, an aliquot of $10 \mu \mathrm{L}$ of sample that was subjected to analysis by HPLC Agilent 1260 (Agilent $^{\text {TM }}$, Germany) combined with a mass spectrometer hybrid triple quadrupole/LIT instrument (3200QTRAP $®$-linear ion trap) (ABSciex, Ontario, Canada). The samples were analysed using an Agilent Zorbax Eclipse XDB-C18 column $\left(50 \times 4.6 \mathrm{~mm} \mathrm{ID}, 1.8 \mu \mathrm{m}\right.$ column at $\left.25^{\circ} \mathrm{C}\right)$. The eluent flow was 0.7 $\mathrm{mL} / \mathrm{min}$ and the mobile phase for positive mode analysis was $0.1 \%$ formic acid (Sigma-Aldrich; LC-MS Grade) in water (solvent A) and acetonitrile (solvent B) (J.T. Baker, Philipsburg, NJ, USA). A linear gradient of $0.7 \mathrm{~mL} / \mathrm{min}$ was used, starting with a mixture of solvent $A(95 \%)$ and solvent $B(5 \%)$. The percentage of solvent $A$ was decreased linearly from $95-5 \%$ over $5 \mathrm{~min}$, and this condition was maintained for $1 \mathrm{~min}$. This mixture was then returned to initial conditions over $2 \mathrm{~min}$ and the analytes were detected and quantified using the electrospray ionisation (ESI) and multiple reaction monitoring (MRM), with the selection of a precursor ion and two ion products to quantify and qualify each compound. The data were recorded and processed using the Analyst 1.5.2 software (ABSciex). The MRM parameters for positive and negative ion modes, limit of detection (LOD) and limit of quantification (LOQ) are shown in Table S1.

\subsection{Ecological risk assessment}

The ecological risk assessment followed the work of Roveri et al. (2021b). The risk quotient (RQ) for aquatic species from three trophic levels (algae, crustaceans and fishes) was calculated from the equation RQ = MEC/PNEC, in which MEC is the maximum Measured Environmental Concentration, and PNEC the Predicted No Effect Concentration, both expressed in $\mathrm{ng} / \mathrm{L}$. The PNEC values for the acute and chronic toxicity data were obtained from the Ecotoxicology Database (ECOTOX) (USEPA, 2019), as well 
as in other literature sources using the PubMed database (see Table S2). When ecotoxicity laboratory experimentally derived data were not available, PNEC was estimated using the Ecological Structure Activity Relationships Programme (ECOSAR, v 2.0) (USEPA, 2017). An attempt was made to compile specifically PNEC data for marine coastal species. However, due to the strong land-sea interaction in this study area and the lack of marine toxicity data, the freshwater species were also taken into consideration in the present study (Roveri et al., 2021a). The PNEC values for the acute and chronic toxicity data were thereafter calculated by dividing each toxicological endpoint by an assessment factor (AF). For saltwater environments, an AF of 10,000 and 100 should be considered in short- and long-term data sets, respectively. The toxicological endpoints selected for the calculation of the PNECs are shown in Table S2. Finally, $R Q$ was categorised into four levels: no $(R Q<0.01)$, low $(0.01 \leq R Q<0.1)$, moderate $(0.1 \leq R Q<$ $1.0)$ and high ecological risk ( $R Q \geq 1.0)$ to aquatic organisms (Hernando et al. 2006).

\section{Results And Discussion}

This study detected, for the first time, the occurrence of several PPCPs, along the entire coast of SC, Brazil. The state's economy is characterized by activities related to tourism, agriculture and industries, with a predominance of textile, ceramic and metal-mechanics industries (SEBRAE, 2013; FIESC, 2021). Moreover, SC is rich in surface freshwater resources which flow into the coastal water of the Atlantic Ocean (ANA, 2021). The occurrence of PPCPs was evaluated in eight sampling points in a coastal marine latitudinal gradient from North to South in areas under strong influence of riverine flow. These surface water bodies belong to five hydrographic regions, where the main and most densely populated cities are located, and where the industrial park of the state is concentrated (SEBRAE, 2013; IBGE, 2020). The screening of the pre-selected twenty-seven PPCPs was based on the annual consumption, reported toxicity and environmental persistence (Cmed, 2021; Roveri et al. 2021b). These PPCPs, were recently identified as having the greatest relevance for studies of environmental monitoring in Brazil (Chaves et al., 2021). The occurrence of these chemical compounds was somewhat expected in the hereby study area as result of the wastewater discharges from industrial and domestic effluents (Krogh et al., 2017; Asfa et al., 2020; Shahriar et al., 2021).

\subsection{Overall occurrence of PPCPs on the coastal waters of Santa Catarina}

From the twenty-seven chemical compounds assessed, it was possible to quantitatively (>LOQ) identify nine compounds. Caffeine (12.58-119.80 ng/L), diclofenac (1.398-7.920 ng/L), losartan (0.432-3.200 $\mathrm{ng} / \mathrm{L})$, cocaine (0.0248-0.1686 ng/L) and benzoylecgonine (0.0146-1.094 $\mathrm{ng} / \mathrm{L})$ were quantified in all sampling points. The carbamazepine $(0.0242-0.2720 \mathrm{ng} / \mathrm{L})$ quantified in $75 \%$ of the samples. The acetaminophen (0.212-10.040 ng/L) was quantified in $60 \%$ of the samples. Both the atenolol (1.13-2.50 $\mathrm{ng} / \mathrm{L})$ and orphenadrine $(0.073-0.0886 \mathrm{ng} / \mathrm{L})$ were quantified in $25 \%$ of the samples. Figure 2 shows the occurrence of each compound, revealing similar profiles for cocaine, caffeine, diclofenac and losartan, with the greatest amounts being consistently reported on the north coast and north-central coast. 
Overall, the MEC of these PPCPs, i.e., $119.8 \mathrm{ng} / \mathrm{L}$ (caffeine), $10.040 \mathrm{ng} / \mathrm{L}$ (acetaminophen), $7.920 \mathrm{ng} / \mathrm{L}$ (diclofenac), $3.2 \mathrm{ng} / \mathrm{L}$ (losartan), $2.5 \mathrm{ng} / \mathrm{L}$ (atenolol), $1.094 \mathrm{ng} / \mathrm{L}$ (benzoylecgonine), $0.272 \mathrm{ng} / \mathrm{L}$ (carbamazepine) and $0.169 \mathrm{ng} / \mathrm{L}$ (cocaine), were similar or lower to the values reported in other parts of the world, including Brazil (For more details, see also Table S3). For instance, high concentrations of the caffeine (MEC: $3000 \mathrm{ng} / \mathrm{L}$ ) were detected in coastal waters of the Red Sea in Saudi Arabia (Ali et al., 2017). In China, in Xiamen Bay, acetaminophen concentrations in range of $0.137 \mathrm{ng} / \mathrm{L}-5.483 \mathrm{ng} / \mathrm{L}$ were measured (Chen et al., 2021). In Brazil, on the coast of the Guarujá city, São Paulo, was detected the occurrence of caffeine (33.5 ng/L - $6550.0 \mathrm{ng} / \mathrm{L})$, valsartan $(19.8 \mathrm{ng} / \mathrm{L}-798 \mathrm{ng} / \mathrm{L})$, losartan $(3.6 \mathrm{ng} / \mathrm{L}-$ $548 \mathrm{ng} / \mathrm{L})$, acetaminophen ( $18.3 \mathrm{ng} / \mathrm{L}-391.0 \mathrm{ng} / \mathrm{L})$, benzoylecgonine $(0.9 \mathrm{ng} / \mathrm{L}-278.0 \mathrm{ng} / \mathrm{L})$, atenolol $(0.1 \mathrm{ng} / \mathrm{L}-140.0 \mathrm{ng} / \mathrm{L})$, diclofenac $(0.9 \mathrm{ng} / \mathrm{L}-85.7 \mathrm{ng} / \mathrm{L})$, among others (Roveri et al., 2020a). In the coastal waters of Santos, Brazil, losartan was found in similar concentrations (<LOD - $3.4 \mathrm{ng} / \mathrm{L}$ ) (Roveri et al., 2020b), or slightly higher concentrations (0.2 ng/L - $8.6 \mathrm{ng} / \mathrm{L})$ (Cortez et al., 2018).

In the existent published studies regarding the coastal area of Brazil (Table S3), the most frequently identified compounds are caffeine, acetaminophen, atenolol, orphenadrine, diclofenac, losartan and carbamazepine. Moreover, a recent review study showed that acetaminophen, caffeine and diclofenac represent the greatest threats to the aquatic environment in Brazil (Chaves et al., 2021), confirming the hereby findings.

\subsection{Spatial distribution of PPCPs on the coastal waters of Santa Catarina}

The spatial distribution of the screened PPCPs in the coastal waters of SC is shown in Figures 2 and 3 , which highlight the sampling points with the highest and lowest occurrences, as well as the MEC of the reported compounds. The largest number of PPCPs was detected at points P3 and P5, belonging to the central-north and central coast, respectively. At these points, the highest concentrations of PPCPs were also found ( $67 \%$ of the reported values). Moreover, atenolol and orphenadrine were only recorded here. Caffeine, diclofenac, losartan and cocaine were detected at all sampling points along the coast of SC. The ubiquous presence of caffeine can be a strong indicator of water contamination by inadequately treated sewage (Li et al., 2020). High levels of caffeine associated with the presence of sanitary effluent have been found in inland and coastal waters in Brazil and in other parts of the world, suggesting that it can be used as a tracer of anthropogenic activity (Li et al., 2020; Rigueto et al., 2020; Roveri et al., 2020a). According to the National Water Agency (ANA), SC has a low sewage treatment coverage rate, with only $24 \%$ of the population served (ANA, 2021). The occurrence of caffeine in significant amounts in the aquatic ecosystem may be associated with the consumption of coffee and tea, drinks that are widely appreciated by the Brazilian people (Souza et al., 2013). Although the concentrations detected in this study were low compared to other reports (Table S3) probably because of the estuarine dispersion to the coastal area, in the absence of additional information to safely assess the real influence of this compound in the aquatic environment, precaution is recommended regarding its effects of the aquatic biota (Korekar et al., 2020). The concentrations of acetaminophen ( $0.212 \mathrm{ng} / \mathrm{L}-10.040 \mathrm{ng} / \mathrm{L})$ and diclofenac $(1.398 \mathrm{ng} / \mathrm{L}-7.920 \mathrm{ng} / \mathrm{L})$ found in this study were similar to the levels found in other areas 
[e.g., Roveri et al. $2020 \mathrm{~b}$ (0.0014 ng/L to 1.4000 ng/L); Ojemaye and Petrick, 2021 (3.7 ng/L to 4.18 $\mathrm{ng} / \mathrm{L})]$.

The other identified drugs, such as losartan, atenolol, orphenadrine, carbamazepine, valsartan and propranolol, were found in low concentrations compared to other studies (Table S3: Cortez et al., 2018; Roveri et al., 2020a; Yang et al., 2020). However, the fact that they have been positively quantified demonstrates that they have significance in environmental analysis. These low values may reflect seawater dilution or environmental degradation processes, which need to be taken into account in the ecological assessment (Biel-Maeso et al., 2018). Furthermore, other factors such as bioaccumulation and the mixture of compounds in the aquatic environment, generating other metabolites, can magnify the effects of these pollutants on the environment, and therefore these PPCPs should be a matter of concern and frequent monitoring (Cizmas et al., 2015; Yin et al., al. 2017; Brew et al., 2020). Recently, a hospital wastewater was investigated in south of Brazil, being detected 43 PPCPs and 31 metabolic products; thereafter a quantitative structure-activity relationship modelation, predicted the effect of both parental compounds and metabolites, based on their degradability and bioaccumulative proprieties, revealing that they could be toxic to the environment and human health (Wielens Becker et al., 2020). In almost all sampling points, the compounds detected more frequently and in greater quantity were caffeine, diclofenac and losartan, with the maximum values detected in the sampling points located on the north coast (P1: losartan and diclofenac) and centre-north (P3: caffeine and losartan). These sampling points are influenced by large rivers and the largest watershed in the SVA, Itajaí Hydrographic Basin, and nearby two of the largest cities in the state, namely Blumenau (309,011 inhabitants) and Joinville (515.288 inhabitants) (Ibge, 2010). The reported values, associated with a greater concentration of people in these regions, allow us to suggest that the presence of PPCPs in coastal waters of SC is mainly due to the contribution of domestic sewage discharged to the ocean through outfalls or due to the freshwater runoff (Dafouz et al., 2018), which are the main routes for contamination of the aquatic environment by these pollutants (Biel-Maeso et al., 2018; Li et al., 2020; Rigueto et al., 2020).

\subsection{Ecological risk assessment}

Table 2 presents the summary data regarding the four chemical compounds that indicated ecological potential risks. The complete data for the nine detected and quantified PPCPs is showed in Table S2. The results show the following trend: (i) in relation to acute toxicity, six of the compounds (acetaminophen, atenolol, benzoylecgonine, carbamazepine, cocaine and orphenadrine) showed no ecotoxicity to algae, crustaceans and fish, while three of them (caffeine, diclofenac, and losartan) showed low to moderate ecotoxicity: caffeine and diclofenac had low ecotoxicity to crustacean and fish, respectively; losartan showed moderate toxicity to crustaceans; (ii) regarding the chronic toxicity, seven of the compounds showed no toxicity to algae, crustaceans, and fish (diclofenac, losartan, atenolol, benzoylecgonine, carbamazepine, cocaine and orphenadrine), while two of them (caffeine and acetaminophen) showed low and moderate toxicity to algae and fish: caffeine had low toxicity to algae, while acetaminophen had moderate toxicity to fish. The hereby reported compounds with potential, acute or chronic, ecotoxicity can cause deleterious effects in the aquatic environment. 
Table 2: Ecological risk assessment results regarding the pharmaceuticals and illicit drug detected in coastal waters along of the Santa Catarina State, southern Brazil. This summary table presents the name of each compound; measured environmental concentration (MEC, ng/L); acute and chronic toxicity data: [(trophic level; organism's test, toxicological endpoint, and concentration (ng/L)]; Assessment Factor (AF); and Predicted No-Effect Concentration (PNEC, ng /L). Data from the toxicological endpoints was obtained from several published works (References) available from the Ecotoxicology Database (ECOTOX), or, in the absence of derived experimentally data, estimated from the ECOSAR program. Note: Freshwater (1); Seawater (2); EC10: 10\% Effective Concentration; EC50: 50\% Effective Concentration; LC50: 50\% Lethal Concentration; NOEC: No Observed Effect. Concentration; LOEC: Lowest Observed Effect Concentration. For further details, see M\&M and Table S3.

Toxicity data

\begin{tabular}{|c|c|c|c|c|c|c|c|c|c|c|}
\hline Coupound & $\begin{array}{l}\text { MEC } \\
\text { (ng L) }\end{array}$ & Trophic & ic level & Organisms/species & Endpoint & Concentrations (ng/L) & $A F$ & $\begin{array}{l}\text { PNEC } \\
(n g / L)\end{array}$ & Reference & $R Q$ \\
\hline \multirow{6}{*}{ Caffeine } & \multirow{6}{*}{119.80} & \multirow{3}{*}{ Acute } & Algae & Pseudokirchnerielia sub́capitata (1) & $72 \mathrm{~h} \mathrm{LC} 50$ & $3.39 \mathrm{E}+08$ & \multirow{3}{*}{10000} & $3.39 \mathrm{E}+05$ & Blaise et al (2005) & $<0.01$ \\
\hline & & & Crustacea & Daphnia dubia (1) & $48 \mathrm{~h} \mathrm{LC50}$ & $5.00 E+07$ & & $5.00 \mathrm{E}+03$ & Moore et al. (2008) & 0.02 \\
\hline & & & Fish & Pimephales promelas (1) & $48 \mathrm{~h} \mathrm{LC50}$ & $8.00 E+07$ & & $8.00 E+03$ & Moore et al. (2008) & 0.01 \\
\hline & & \multirow{3}{*}{ Chronic } & Algae & Lamna gibba & $\mathrm{LOEC} / 2$ & $5.00 \mathrm{E}+05$ & \multirow{3}{*}{100} & $5.00 \mathrm{E}+03$ & Brain et al. (2004) & 0.02 \\
\hline & & & Crustacea & Ceriodaphnia dubia (1) & NOEC & $2.00 \mathrm{E}+07$ & & $2.00 \mathrm{E}+05$ & Brain et al. (2004) & $<0.01$ \\
\hline & & & Fish & Pimephaies promelas (1) & NOEC & $3.00 \mathrm{E}+07$ & & $3.00 E+05$ & Brain et al. (2004) & $<0.01$ \\
\hline \multirow{6}{*}{ Acetaminophen } & \multirow{6}{*}{10.04} & \multirow{3}{*}{ Acute } & Algae & Pharodactyinm tricomutum (2) & $72 \mathrm{~h} \mathrm{BC} 50$ & $2.39 \mathrm{E}+08$ & \multirow{3}{*}{10000} & $2.39 \mathrm{E}+04$ & Claessens et al. (2013) & $<0.01$ \\
\hline & & & Crustacea & Artemia salina ${ }^{(2)}$ & 48h EC50 & $1.00 \mathrm{E}+08$ & & $1.00 E+04$ & Minguez et al (2014) & $\infty 0.01$ \\
\hline & & & Fish & Onyzias latipes (1) & $48 \mathrm{~h} \mathrm{EC50}$ & $2.66 \mathrm{E}+08$ & & $2.66 \mathrm{E}+04$ & Kim et al. (2007) & $<0.01$ \\
\hline & & \multirow{3}{*}{ Chronic } & Algae & Phavodactyium tricormuniom ${ }^{(2)}$ & $72 \mathrm{~h} \mathrm{ECl0}$ & $7.21 \mathrm{E}+07$ & \multirow{3}{*}{100} & $7.21 \mathrm{E}+05$ & Claessens et al. (2013) & $<0.01$ \\
\hline & & & Crustacea & Daphnia magna (1) & NOEC & $4.03 \mathrm{E}+05$ & & $4.03 E+03$ & Kim et al. (2009) & $<0.01$ \\
\hline & & & Fish & Danio rerio (1) & $L O B C / 2$ & $5.00 \mathrm{E}+03$ & & $5.00 \mathrm{E}+01$ & Gahs et al. (2013) & 0.20 \\
\hline \multirow{6}{*}{ Diclofenac } & \multirow{6}{*}{7.92} & \multirow{3}{*}{ Acute } & Algae & Dunalieilia tertiolecta (2) & $96 \mathrm{~h} \mathrm{EC50}$ & $1.86 \mathrm{E}+08$ & \multirow{3}{*}{10000} & $1.86 \mathrm{E}+04$ & DeLorenzo e Fleming (2007) & $<0.01$ \\
\hline & & & Crustacea & Artemia salina (2) & $48 \mathrm{~h} \mathrm{EC50}$ & $1.00 \mathrm{E}+08$ & & $1.00 \mathrm{E}+04$ & Minguez et al (2014) & $<0.01$ \\
\hline & & & Fish & Danio rerio (1) & $72 \mathrm{~h} \mathrm{LC} 50$ & $7.80 \mathrm{E}+06$ & & $7.80 \mathrm{E}+02$ & Van den Brandof e Montforts (2010) & 0.01 \\
\hline & & \multirow{3}{*}{ Chronic } & Algae & Lemna minor (1) & NOEC & $3.75 \mathrm{E}+06$ & \multirow{3}{*}{100} & $3.75 \mathrm{E}+04$ & Cleuvers (2003) & $<0.01$ \\
\hline & & & Crustacea & Coriodaphnia dubia ${ }^{(1)}$ & NOEC & $1.00 \mathrm{E}+06$ & & $1.00 E+04$ & Ferrari et al (2003) & $<0.01$ \\
\hline & & & Fish & Danio rerio (1) & NOEC & $4.00 \mathrm{E}+06$ & & $4.00 \mathrm{E}+04$ & Ferrari et al (2003) & $<0.01$ \\
\hline \multirow{6}{*}{ Losartan } & \multirow{3}{*}{3.20} & \multirow{3}{*}{ Acute } & Algae & Lemna minor ${ }^{(1)}$ & $96 \mathrm{~h} \mathrm{EC50}$ & $6.46 \mathrm{E}+07$ & \multirow{3}{*}{10000} & $6.46 \mathrm{E}+03$ & Godoy et al (2015) & $<0.01$ \\
\hline & & & Crustácea & Daphnia magna (1) & $48 \mathrm{~h} \mathrm{LC50}$ & 331000 & & $3.31 \mathrm{E}+01$ & FDA (2012) & 0.10 \\
\hline & & & Fish & Pimephales promelas (1) & $48 \mathrm{~h} \mathrm{LC50}$ & $1.00 E+09$ & & $1.00 \mathrm{E}+06$ & FDA (2012) & $<0.01$ \\
\hline & & \multirow{3}{*}{ Chronic } & Algae & Alga verde (I) & \multirow{3}{*}{$1^{\prime}\left(\log (\operatorname{LOEC} \mathrm{x} \mathrm{NOEC}) \mathrm{y}^{2}\right)$} & $1.64 \mathrm{E}+06$ & \multirow{3}{*}{100} & $1.64 \mathrm{E}+04$ & ECOSAR & $<0.01$ \\
\hline & & & Crustacea & Dáfnia ${ }^{(1)}$ & & $5.55 \mathrm{E}+05$ & & $5.55 \mathrm{E}+03$ & ECOSAR. & $<0.01$ \\
\hline & & & Fish & Peive (1) & & $2.94 \mathrm{E}+05$ & & $2.94 \mathrm{E}+03$ & ECOSAR & $<0.01$ \\
\hline
\end{tabular}

Caffeine in environmentally relevant concentrations can cause oxidative stress, lipid peroxidation and even mortality to aquatic organisms ( $\mathrm{Li}$ et al., 2020). However, the caffeine concentrations found in this study, in general, do not acutely affect the aquatic environment (Gray et al., 2021). However, the fact that it was detected frequently and in all sampling points, and its direct connection with human activity, suggests the use of caffeine as a potential indicator of the presence of contamination from sanitary effluent discharges (Henderson, 2020; Rigueto et al., 2020; Li et al., 2020). Moreover, investigations carried out in recent years have evaluated the presence of caffeine in tissues of organisms such as fish, molluscs and suggesting bioaccumulation ( $\mathrm{Li}$ et al. 2020; de Sousa et al. 2021). The presence of caffeine in high concentrations in the environment, results in a high-risk quotient for chronic exposure of biota 
(Dafouz et al., 2018), suggesting a high probability of adverse effects in the aquatic compartment (Pires et al., 2016; Santos- Silva et al., 2018; Godoi et al., 2020).

The occurrence of acetaminophen in the hereby reported concentration suggests a ecological risk considered moderate to fish. The toxicity caused by acetaminophen is generally mediated by reactive oxygen species and can result in multiple effects, ranging from protein denaturation to lipid peroxidation and DNA damage (Antunes et al., 2013), mainly as results of oxidative stress mechanisms (Nunes et al., 2014). Recently, it was show that relatively low levels of this compound can exert adaptive changes with unpredictable consequences in the gastropod Phorcus lineatus (Almeida and Nunes, 2019).

Diclofenac presented a low risk to fish. However, existent studies suggest that the presence of this drug and its metabolites may represent a high risk to aquatic biota due to its synergistic interactions with other contaminants (Sathishkumar et al., 2019). Ecotoxicological effects tested through the food chain, using fish (Solea senegalensis) fed with worms (Hediste diversicolor) exposed to environmentally realistic concentrations of diclofenac, showed a significant decrease in the activities of the enzymes catalase and acetylcholinesterase, suggesting that exposure to diclofenac can cause significant physiological and neurotoxic disorders in aquatic organisms (Nunes et al., 2020). Exposure of fish (Danio rerio) embryos and larvae to diclofenac resulted also in oxidative stress problems (Bio and Nunes, 2020). Diclofenac tested on mussel embryos (Mitylus galloprivincialis) affected enzymatic processes of gene transcription and promoted malformation of the physical structure of the shell (Balbi et al., 2018). Moreover, the study of the biotransformation processes occurring in aquatic organisms, namely in amphipod crustacean (e.g., Gammarus pulex and Hyalella azteca) exposed to diclofenac, showed that it produces methylated metabolites, more bioaccumulative and toxic than the parental compound, which should be considered for a comprehensive risk assessment (Fu et al., 2020).

Losartan showed moderate acute toxicity risk to crustaceans. Biological effects of losartan have been already reported in mussels Perna perna exposed to concentrations of losartan up to $3000 \mathrm{ng} / \mathrm{L}$ resulting in cytotoxic effects on gills and hemocytes (Cortez et al., 2018). But, the hereby reported values were much lower (0.432 ng/L to $3.200 \mathrm{ng} / \mathrm{L})$. However, studies carried out in the city of Guarujá, São Paulo, Brazil, detected a significant amounts of losartan $(3.6 \mathrm{ng} / \mathrm{L}-548.0 \mathrm{ng} / \mathrm{L})$ showing that the compound may present moderate to severe risks for algae, crustaceans and fish (Roveri et al., 2020a). Losartan effects were evaluated through inhibition tests with aquatic plants (Lemna minor) (Godoy et al., 2015) and bacteria (Aliivibrio fischeri) (Turek et al., 2020), but no significant toxic effects were observed. Losartan is present in urine in significant concentrations, around 35\% (Guateque-Londoño et al., 2020), not being completely removed in WWTPs (Gurke et al., 2015). Regions with high population density and intense agricultural activities, represent a potential risk to the local ecosystem (Osório et al., 2016), since it causes cytotoxic effects on aquatic organisms (Cortez et al., 2018).

Carbamazepine, cocaine, benzoylecgonine, orphenadrine and atenolol did not present any risk $(R Q<0.01)$ for all trophic levels tested, which does not raise immediate concern regarding their toxic effects in the aquatic environment. However, these PPCPs are not alone in in the aquatic compartment; they are present 
in complex mixtures of chemical compounds, where additive or synergistic effects are expected to occur, causing deleterious effects sometime greater than those caused by the individual drug (Fernandéz et al., 2013; Di Nica et al., 2016). Chronic exposure to a mixture of PPCPs in zebrafish (Danio rerio) altered their metabolism, causing a significant reduction in the hepatosomatic index and histological changes in the liver and intestinal tissues, in addition to other observed effects (Hamid et al., 2021). Similarly, a mixture of PPCPs was tested on freshwater algae (Chlorella vulgaris) observing that the toxic effects of the mixture were greater than the effects of each individual substance (Geiger et al., 2016). Several ecotoxicological tests performed on different aquatic organisms exposed to 10 PPCPs in ecologically relevant concentrations, independently and in mixture, showed that the toxicity was 6.5 times, 100 times and 15,000 times greater than the concentrations of the individual compounds for algae (Pseudokirchneriella subcapitata), daphnia (Ceriodaphia dubia) and fish (Danio rerio), respectively (Watanabe et al., 2016). Other effects of mixtures of PPCPs in water were also observed, such as the increase in antibiotic-resistant bacteria (Cizmas et al., 2015). Moreover, PPCPs present in natural waters, like acetaminophen, which act as drinking water sources, during the chlorination step in conventional water plants could results in the formation of more toxic byproducts, such as trihalomethanes (Ding et al., 2018).

\section{Conclusion}

This work intended to evaluate, for the first time, the presence and ecological risk of PPCPs in the marine coastal environment of Santa Catarina, Brazil. Seawater sampling was carried out in November 2020 in eight estuarine points along the entire coast of SC, and the presence of 27 PPCPs was screened. The investigation detected the presence of nine compounds, namely caffeine, acetaminophen, diclofenac, losartan, atenolol, benzoylecgonine, carbamazepine, cocaine and orphenadrine. The spatial distribution, detection frequency and measured concentrations for six of them, e.g. caffeine, diclofenac, losartan, benzoylecgonine, carbamazepine and cocaine, suggested that these compounds are constantly present on the coast of SC. The ecological risk assessment showed that caffeine, diclofenac, losartan, and acetaminophen presented low to moderate risks for aquatic organisms acutely and chronically exposed to them. SC is a state whose tourism is constant, especially in the coastal region. The low rate of sewage collection and treatment in the state, associated with traditional WWTP, explain why such PPCPs are continuously discharged into receiving water bodies, contaminating the inshore environment. Thus, it is recommended to expand and improve the basic sanitation infrastructures, opting for advanced technologies for the removal of PPCPs in the WWTP. The establishment of periodic monitoring for PPCPs compounds, jointly with other parameters of quality of bathing waters, is also highly recommended. In addition, public awareness actions about the proper use, control and disposal of medicines and hygiene products are extremely important to minimize the discharge of these compounds into the aquatic environment, namely in areas of intense human recreation.

\section{Declarations}




\section{Acknowledgments}

Authors want to acknowledge Daniel Temponi Lebre from the Centro de Espectrometria de Massa Aplicada - Instituto de Pesquisas Energéticas e Nucleares (CEMSA, IPEN, São Paulo, Brazil) for technical support regarding the LC-MS/MS analyses. Thanks also to Professor Ítalo Braga de Castro, from Instituto do Mar, Universidade Federal de São Paulo (IMAR-UNIFESP, São Paulo, Brazil) for technical support with the Manifold.

\section{Ethics approval and consent to participate}

Not applicable.

\section{Consent for publication}

Not applicable.

\section{Availability of data and materials}

Not applicable.

\section{Competing interests}

The authors declare that they have no competing interests.

\section{Authors' contributions}

AMP: Conceptualization, sampling acquisition, data analysis, and writing of the original draft. VR: Laboratorial work, review \& editing of the MS. LLG: Laboratorial work, Review \& editing. TMNO: Review \& editing, and co-supervision. ATC: Sampling design, funding acquisition, supervision, writing - original draft, and writing - review \& editing.

\section{Funding}

Correia AT was supported by national funds through FCT - Foundation for Science and Technology within the scope of UIDB/04423/2020 and UIDP/04423/2020.

\section{References}

1. Afsa S, Hamden K, Lara Martin PA, Mansour HB (2020) Occurrence of 40 pharmaceutically active compounds in hospital and urban wastewaters and their contribution to Mahdia coastal seawater contamination. Environ Sci Pollut Res 27(2):1941-1955. https://doi.org/10.1007/s11356-01906866-5

2. Al-Farsi RS, Ahmed M, Al-Busaidi A, Choudri BS (2017) Translocation of pharmaceuticals and personal care products (PPCPs) into plant tissues: A review. Emerging Contaminants 3(4):132-137. 
https://doi.org/10.1016/j.emcon.2018.02.001

3. Ali AM, Rønning HT, Alarif W, Kallenborn R, Al-Lihaibi SS (2017) Occurrence of pharmaceuticals and personal care products in effluent-dominated Saudi Arabian coastal waters of the Red Sea. Chemosphere 175:505-513. https://doi.org/10.1016/j.chemosphere.2017.02.095

4. Almeida F, Nunes B (2019) Effects of acetaminophen in oxidative stress and neurotoxicity biomarkers of the gastropod Phorcus lineatus. Environ Sci Pollut Res 26(10):9823-9831. https://doi.org/10.1007/s11356-019-04349-1

5. Álvarez-Ruiz R, Andrés-Costa MJ, Andreu V, Picó Y (2015) Simultaneous determination of traditional and emerging illicit drugs in sediments, sludges and particulate matter. J Chromatogr A 1405:103115. https://doi.org/10.1016/j.chroma.2015.05.062

6. ANA. Agência Nacional de Águas (Brasil). Atlas esgotos: despoluição de bacias hidrográficas / Agência Nacional de Águas, Secretaria Nacional de Saneamento Ambiental. -- Brasília: ANA, 2017. Em linha: Disponível em: < SNIS - Diagnóstico dos Serviços de Água e Esgotos - 2019. Acesso em 2021.

7. ANA. Agência Nacional de Águas (Brasil). Ministério do Meio Ambiente. Guia Nacional de Coleta e Preservação de Amostras: Água, Sedimento, Comunidades Aquáticas e Efluentes Líquidos, p. 327 (2011) Cetesb, São Paulo, SP, Brasil. Em linha: Disponível em: http://arquivos.ana.gov.br/institucional/sge/CEDOC/Catalogo/2012/GuiaNacionalDeColeta.pdf. Acesso em 2017

8. Antunes SC, Freitas R, Figueira E, Gonçalves F, Nunes B (2013) Biochemical effects of acetaminophen in aquatic species: Edible clams Venerupis decussata and Venerupis philippinarum. Environ Sci Pollut Res 20(9):6658-6666. https://doi.org/10.1007/s11356-013-1784-9

9. APHA. Standard Methods for the Examination of Water and Wastewater, 22st Edition (2012) Método 1060 B e C

10. Baena-Nogueras RM, González-Mazo E, Lara-Martín PA (2017) Degradation kinetics of pharmaceuticals and personal care products in surface waters: Photolysis vs biodegradation. Sci Total Environ 590-591:643-654. https://doi.org/10.1016/j.scitotenv.2017.03.015

11. Balakrishna K, Vijayasarathy S, Praveenkumarreddy Y, Gopal C, Eaglesham G, Jiang H, Bhat K (2018) First report of pharmaceuticals and personal care products in the sea-ice of Larsemann Hills, Eastern Antarctica. Dioxin 2018, Krakow,Poland. https://eprints.manipal.edu/152968/

12. Balbi T, Montagna M, Fabbri R, Carbone C, Franzellitti S, Fabbri E, Canesi L (2018) Diclofenac affects early embryo development in the marine bivalve Mytilus galloprovincialis. Sci Total Environ 642:601-609. https://doi.org/10.1016/j.scitotenv.2018.06.125

13. Bartrons M, Peñuelas J (2017) Pharmaceuticals and Personal-Care Products in Plants. Trends Plant Sci 22(3):194-203. https://doi.org/10.1016/j.tplants.2016.12.010

14. Behera SK, Kim HW, Oh J-E, Park H-S (2011) Occurrence and removal of antibiotics, hormones and several other pharmaceuticals in wastewater treatment plants of the largest industrial city of Korea. Sci Total Environ 409(20):4351-4360. https://doi.org/10.1016/j.scitotenv.2011.07.015 
15. Beretta M, Britto V, Tavares TM, da Silva SMT, Pletsch AL (2014) Occurrence of pharmaceutical and personal care products (PPCPs) in marine sediments in the Todos os Santos Bay and the north coast of Salvador, Bahia, Brazil. J Soils Sediments 14(7):1278-1286. https://doi.org/10.1007/s11368-0140884-6

16. Biel-Maeso M, Baena-Nogueras RM, Corada-Fernández C, Lara-Martín PA (2018) Occurrence, distribution and environmental risk of pharmaceutically active compounds (PhACs) in coastal and ocean waters from the Gulf of Cadiz (SW Spain). Sci Total Environ 612:649-659. https://doi.org/10.1016/j.scitotenv.2017.08.279

17. Bio S, Nunes B (2020) Acute effects of diclofenac on zebrafish: Indications of oxidative effects and damages at environmentally realistic levels of exposure. Environ Toxicol Pharmacol 78:103394. https://doi.org/10.1016/j.etap.2020.103394

18. Blaise C, Gagné F, Eullaffroy P, Férard J-F (2006) Ecotoxicity of selected pharmaceuticals of urban origin discharged to the Saint-Lawrence river (Québec, Canada): A review. Ecotoxicity of selected pharmaceuticals of urban origin discharged to the Saint-Lawrence river (Québec, Canada): a review.Brazilian Journal of Aquatic Science and Technology. https://agris.fao.org/agrissearch/search.do? recordID=DJ2012060278

19. Brain RA, Johnson DJ, Richards SM, Hanson ML, Sanderson H, Lam MW, Young C, Mabury SA, Sibley PK, Solomon KR (2004) Microcosm evaluation of the effects of an eight pharmaceutical mixture to the aquatic macrophytes Lemna gibba and Myriophyllum sibiricum. Aquat Toxicol 70(1):23-40. https://doi.org/10.1016/j.aquatox.2004.06.011

20. Brew DW, Black MC, Santos M, Rodgers J, Henderson WM (2020) Metabolomic Investigations of the Temporal Effects of Exposure to Pharmaceuticals and Personal Care Products and Their Mixture in the Eastern Oyster (Crassostrea virginica). Environ Toxicol Chem 39(2):419-436. https://doi.org/10.1002/etc.4627

21. Calleja MC, Persoone G, Geladi P (1994) Comparative acute toxicity of the first 50 Multicentre Evaluation of In Vitro Cytotoxicity chemicals to aquatic non-vertebrates. Arch Environ Contam Toxicol 26(1):69-78. https://doi.org/10.1007/BF00212796

22. Chaves M, de Barbosa JS, Primel EG (2021) Emerging contaminants in Brazilian aquatic environment: Identifying targets of potential concern based on occurrence and ecological risk. Environ Sci Pollut Res. https://doi.org/10.1007/s11356-021-15245-y

23. Chen H, Chen W, Guo H, Lin H, Zhang Y (2021) Pharmaceuticals and personal care products in the seawater around a typical subtropical tourist city of China and associated ecological risk. Environ Sci Pollut Res 28(18):22716-22728. https://doi.org/10.1007/s11356-020-12335-1

24. Chiavelli HGR, Torrecilhas AR, Sella MR, Cardoso MAP, Martin DR (2019) ([s.d.]). Remoção de fármacos por adsorção em carvão ativado granular e pulverizado em águas de abastecimento. 12. IX Congresso Brasileiro de Engenharia de Produção. Ponta Grossa, PR, Brasil, $<$ 10212019_141054_5dadea9a06738.pdf (aprepro.org.br)\&gt 
25. Cizmas L, Sharma VK, Gray CM, McDonald TJ (2015) Pharmaceuticals and personal care products in waters: Occurrence, toxicity, and risk. Environ Chem Lett 13(4):381-394.

https://doi.org/10.1007/s10311-015-0524-4

26. Claessens M, Vanhaecke L, Wille K, Janssen CR (2013) Emerging contaminants in Belgian marine waters: Single toxicant and mixture risks of pharmaceuticals. Mar Pollut Bull 71(1):41-50. https://doi.org/10.1016/j.marpolbul.2013.03.039

27. Cleuvers $M$ (2003) Aquatic ecotoxicity of pharmaceuticals including the assessment of combination effects. Toxicol Lett 142(3):185-194. https://doi.org/10.1016/S0378-4274(03)00068-7

28. CMED - Câmara de Regulação do Mercado de Medicamentos, Brasília (2021) Anuário Estatístico do Mercado Farmacêutico. CMED publica o Anuário Estatístico do Mercado Farmacêutico - Edição Comemorativa 2019/2020 - Português (Brasil) (www.gov.br). ANVISA. http://portal.anvisa.gov.br/ Acesso em Julho de 2021.

29. Cortez FS, Souza LdaS, Guimarães LL, Almeida JE, Pusceddu FH, Maranho LA, Mota LG, Nobre CR, Moreno BB, Abessa DM, de Cesar S, Santos A, Pereira CDS (2018) Ecotoxicological effects of losartan on the brown mussel Perna perna and its occurrence in seawater from Santos Bay (Brazil). Sci Total Environ 637-638:1363-1371. https://doi.org/10.1016/j.scitotenv.2018.05.069

30. Costa Junior IL, Pletsch AL, Torres YR (2014) Occurrence of Antidepressant Drugs in the Environment -A Review. Revista Virtual de Química 6(5). https://doi.org/10.5935/1984-6835.20140092

31. Dafouz R, Cáceres N, Rodríguez-Gil JL, Mastroianni N, López de Alda M, Barceló D, de Miguel ÁG, Valcárcel $Y$ (2018) Does the presence of caffeine in the marine environment represent an environmental risk? A regional and global study. Sci Total Environ 615:632-642. https://doi.org/10.1016/j.scitotenv.2017.09.155

32. Daughton CG (2007) Chapter 1 Pharmaceuticals in the environment: Sources and their management. In M. Petrović \& D. Barceló (Orgs.), Comprehensive Analytical Chemistry (Vol. 50, p. 1-58). Elsevier. https://doi.org/10.1016/S0166-526X(07)50001-2

33. De Sousa ML, dos Santos DYAC, Chow F, Pompêo MLM (2021) Caffeine as a contaminant of periphyton: Ecological changes and impacts on primary producers. Ecotoxicology 30(4):599-609. https://doi.org/10.1007/s10646-021-02381-x

34. Del Rosario KL, Mitra S, Humphrey CP, O’Driscoll MA (2014) Detection of pharmaceuticals and other personal care products in groundwater beneath and adjacent to onsite wastewater treatment systems in a coastal plain shallow aquifer. Sci Total Environ 487:216-223. https://doi.org/10.1016/j.scitotenv.2014.03.135

35. DeLorenzo ME, Fleming J (2008) Individual and Mixture Effects of Selected Pharmaceuticals and Personal Care Products on the Marine Phytoplankton Species Dunaliella tertiolecta. Arch Environ Contam Toxicol 54(2):203-210. https://doi.org/10.1007/s00244-007-9032-2

36. Di Nica V, Villa S, Finizio A (2016) Toxicity of individual pharmaceuticals and their mixtures to Aliivibrio fischeri: experimental results for single compounds and considerations of their 
mechanisms of action and potential acute effects on aquatic organisms. Environ Toxicol Chem 36(3):807-814. https://doi.org/10.1002/etc.3568

37. Diamanti K, Aalizadeh R, Alygizakis N, Galani A, Mardal M, Thomaidis NS (2019) Wide-scope target and suspect screening methodologies to investigate the occurrence of new psychoactive substances in influent wastewater from Athens. Sci Total Environ 685:1058-1065. https://doi.org/10.1016/j.scitotenv.2019.06.173

38. Ding S, Chu W, Bond T, Wang Q, Gao N, Xu B, Du E (2018) Formation and estimated toxicity of trihalomethanes, haloacetonitriles, and haloacetamides from the chlor(am)ination of acetaminophen. J Hazard Mater 341:112-119. https://doi.org/10.1016/j.jhazmat.2017.07.049

39. Ebele AJ, Abou-Elwafa Abdallah M, Harrad S (2017) Pharmaceuticals and personal care products (PPCPs) in the freshwater aquatic environment. Emerging Contaminants 3(1):1-16. https://doi.org/10.1016/j.emcon.2016.12.004

40. Ekpeghere KI, Sim W-J, Lee H-J, Oh J-E (2018) Occurrence and distribution of carbamazepine, nicotine, estrogenic compounds, and their transformation products in wastewater from various treatment plants and the aquatic environment. Sci Total Environ 640-641:1015-1023. https://doi.org/10.1016/j.scitotenv.2018.05.218

41. EMA - European Medicines Agency, Committee for Medicinal Products for Human use (CHMP) (2006) Guideline on the Environmental Risk Assessment of Medicinal Products for Human use. Doc. Ref.: EMEA/CHMP/SWP/4447/00 corr 1, London, UK

42. Emnet P, Gaw S, Northcott G, Storey B, Graham L (2015) Personal care products and steroid hormones in the Antarctic coastal environment associated with two Antarctic research stations, McMurdo Station and Scott Base. Environ Res 136:331-342. https://doi.org/10.1016/j.envres.2014.10.019

43. Evgenidou EN, Konstantinou IK, Lambropoulou DA (2015) Occurrence and removal of transformation products of PPCPs and illicit drugs in wastewaters: A review. Sci Total Environ 505:905-926. https://doi.org/10.1016/j.scitotenv.2014.10.021

44. FDA - U.S. Food and Drug Administration (2012) Center for drug evaluation and research. Approach Package for: Aplication number 20-386/S-019 and 029. Environment Assesment/ Fonsi, p 8

45. Fernández C, Carbonell G, Babín M (2013) Effects of individual and a mixture of pharmaceuticals and personal-care products on cytotoxicity, EROD activity and ROS production in a rainbow trout gonadal cell line (RTG-2). J Appl Toxicol 33(11):1203-1212. https://doi.org/10.1002/jat.2752

46. Ferrari, B., Paxéus, N., Giudice, R. L., Pollio, A., \& Garric, J. (2003). Ecotoxicological impact of pharmaceuticals found in treated wastewaters: Study of carbamazepine, clofibric acid, and diclofenac. Ecotoxicology and Environmental Safety, 55(3), 359-370. https://doi.org/10.1016/S0147-6513(02)00082-9

47. FIESC - Federação das Indústrias do Estado de Santa Catarina. Observatório. Economia de Santa Catarina. Em linha: Disponível em: < https://www.observatoriofiesc.com.br/resumo-executivo>. Acesso em: 2020. 
48. FIESC - Federação das Indústrias do Estado de Santa Catarina (2021) Observatório. Economia de Santa Catarina. Em linha: Disponível em:. Acesso em:

49. Filho NHH (2003) Setorização da Província Costeira de Santa Catarina em base aos aspectos geológicos, geomorfológicos e geográficos. Geosul, 18(35), 71-98. Em linha: Disponível em. Acesso em 2021.

50. Fontes MK, de Campos BG, Cortez FS, Pusceddu FH, Moreno BB, Maranho LA, Lebre DT, Guimarães LL, Pereira CDS (2019) Seasonal monitoring of cocaine and benzoylecgonine in a subtropical coastal zone (Santos Bay, Brazil). Mar Pollut Bull 149:110545. https://doi.org/10.1016/j.marpolbul.2019.110545

51. de Freitas L, Radis-Baptista G (2021) Pharmaceutical Pollution and Disposal of Expired, Unused, and Unwanted Medicines in the Brazilian Context. Journal of Xenobiotics 11(2):61-76. https://doi.org/10.3390/jox11020005

52. Fu Q, Fedrizzi D, Kosfeld V, Schlechtriem C, Ganz V, Derrer S, Rentsch D, Hollender J (2020) Biotransformation Changes Bioaccumulation and Toxicity of Diclofenac in Aquatic Organisms. Environ Sci Technol 54(7):4400-4408. https://doi.org/10.1021/acs.est.9b07127

53. Galus M, Kirischian N, Higgins S, Purdy J, Chow J, Rangaranjan S, Li H, Metcalfe C, Wilson JY (2013) Chronic, low concentration exposure to pharmaceuticals impacts multiple organ systems in zebrafish. Aquatic Toxicology, 132-133, 200-211. https://doi.org/10.1016/j.aquatox.2012.12.021

54. Geiger E, Hornek-Gausterer R, Saçan MT (2016) Single and mixture toxicity of pharmaceuticals and chlorophenols to freshwater algae Chlorella vulgaris. Ecotoxicol Environ Saf 129:189-198. https://doi.org/10.1016/j.ecoenv.2016.03.032

55. Ghoshdastidar AJ, Fox S, Tong AZ (2015) The presence of the top pre- 973 scribed pharmaceuticals in treated sewage effluents and receiving 974 waters in Southwest Nova Scotia, Canada. Environ Sci Pollut Res 975 22(1):689-700. https://doi.org/10.1007/s11356-014-3400-z

56. Godoi FGA, Muñoz-Peñuela M, Gomes ADO, Tolussi CE, Brambila-Souza G, Branco GS, Nostro L, Moreira RG (2020) Endocrine disruptive action of diclofenac and caffeine on Astyanax altiparanae males (Teleostei: Characiformes: Characidae). Comp Biochem Physiol C: Toxicol Pharmacol 231:108720. https://doi.org/10.1016/j.cbpc.2020.108720

57. Godoy AA, Kummrow F, Pamplin PAZ (2015) Ecotoxicological evaluation of propranolol hydrochloride and losartan potassium to Lemna minor L. (1753) individually and in binary mixtures. Ecotoxicology 24(5):1112-1123. https://doi.org/10.1007/s10646-015-1455-3

58. Goldstein M, Shenker M, Chefetz B (2014) abril 30). Insights into the Uptake Processes of Wastewater-Borne Pharmaceuticals by Vegetables (world) [Research-article]. American Chemical Society. https://doi.org/10.1021/es5008615

59. Gray I, Green-Gavrielidis LA, Thornber C (2021) Effect of caffeine on the growth and photosynthetic efficiency of marine macroalgae. Bot Mar 64(1):13-18. https://doi.org/10.1515/bot-2020-0055

60. Guateque-Londoño JF, Serna-Galvis EA, Ávila-Torres Y, Torres-Palma RA (2020) Degradation of Losartan in Fresh Urine by Sonochemical and Photochemical Advanced Oxidation Processes. Water, 
12(12), 3398. https://doi.org/10.3390/w12123398, apud Israili, Z. (2000). Clinical pharmacokinetics of angiotensin II (AT1) receptor blockers in hypertension. Journal of Human Hypertension, 14(S1), S73-S86. https://doi.org/10.1038/sj.jhh.1000991

61. Gurke R, Rößler M, Marx C, Diamond S, Schubert S, Oertel R, Fauler J (2015) Occurrence and removal of frequently prescribed pharmaceuticals and corresponding metabolites in wastewater of a sewage treatment plant. Sci Total Environ 532:762-770. https://doi.org/10.1016/j.scitotenv.2015.06.067

62. Hamid N, Junaid M, Wang Y, Pu S-Y, Jia P-P, Pei D-S (2021) Chronic exposure to PPCPs mixture at environmentally relevant concentrations (ERCs) altered carbohydrate and lipid metabolism through gut and liver toxicity in zebrafish. Environ Pollut 273:116494.

https://doi.org/10.1016/j.envpol.2021.116494

63. Heinz D, de Moreno GC, Hein N (2020) O saneamento básico nos municípios de Santa Catarina: Uma análise cluster. COLÓQUIO - Revista do Desenvolvimento Regional 18(1):1-15. https://doi.org/10.26767/coloquio.v18i1.1888

64. Henderson A, Ng B, Landeweer S, Quinete N, Gardinali P (2020) Assessment of Sucralose, Caffeine and Acetaminophen as Anthropogenic Tracers in Aquatic Systems Across Florida. Bull Environ Contam Toxicol 105(3):351-357. https://doi.org/10.1007/s00128-020-02942-6

65. Hernando MD, Mezcua M, Fernández-Alba AR, Barceló D (2006) Environmental risk assessment of pharmaceutical residues in wastewater effluents, surface waters and sediments. Talanta 69(2):334342. https://doi.org/10.1016/j.talanta.2005.09.037

66. Huber S, Remberger M, Kaj L, Schlabach M, Jörundsdóttir H, Vester J, Arnórsson M, Mortensen I, Schwartson R, Dam M (2016) A first screening and risk assessment of pharmaceuticals and additives in personal care products in waste water, sludge, recipient water and sediment from Faroe Islands, Iceland and Greenland. Sci Total Environ 562:13-25.

https://doi.org/10.1016/j.scitotenv.2016.03.063

67. IBGE - Instituto Brasileiro de Geografia e Estatística. Censo Ibge 2010. Em linha: Disponível em:< https://censo2010.ibge.gov.br. Acesso em 2017

68. IBGE - Instituto Brasileiro de Geografia e Estatística. Cidades e Estados: Santa Catarina. https://www.ibge.gov.br/cidades-e-estados/sc/. Acesso em 2020

69. INMETRO (2011) Instituto Nacional de Metrologia, Normalização e Qualidade Industrial. Orientação sobre validação de métodos de ensaios químicos. Rio de Janeiro. Brasil. DOQ-CGCRE-008.

70. Kallenborn R, Brorström-Lundén E, Reiersen L-O, Wilson S (2018) Pharmaceuticals and personal care products (PPCPs) in Arctic environments: Indicator contaminants for assessing local and remote anthropogenic sources in a pristine ecosystem in change. Environ Sci Pollut Res 25(33):3300133013. https://doi.org/10.1007/s11356-017-9726-6

71. Kaza. M., Nalecz-Jawecki, G., Sawicki, J. (2007). The Toxicity Of Selected Pharmaceuticals To The Aquatic Plant Lemna Minor. Fresenius Environmental Bulletin 16(5):524-531

72. Keerthanan, S., Jayasinghe, C., Biswas, J. K., \& Vithanage, M. (2021). Pharmaceutical and Personal Care Products (PPCPs) in the environment: Plant uptake, translocation, bioaccumulation, and human 
health risks. Critical Reviews in Environmental Science and Technology, 51(12), 1221-1258. https://doi.org/10.1080/10643389.2020.1753634

73. Kim, J. W., Yoon, S. M., Lee, S. J., Narumiya, M., Nakada, N., Han, I. S., \& Tanaka, H. (2012). Occurrence and Fate of PPCPs Wastewater Treatment Plants in Korea. 5. Em linha: Disponível em:< 012-ICEII2012-E029.pdf (ipcbee.com)> Acesso em 2020.

74. Kim J-W, Ishibashi H, Yamauchi R, Ichikawa N, Takao Y, Hirano M, Arizono K (2009) Acute toxicity of pharmaceutical and personal care products on freshwater crustacean (Thamnocephalus platyurus) and fish (Oryzias latipes). J Toxicol Sci 34(2):227-232. doi:10.2131/jts.34.227

75. Kim Y, Choi K, Jung J, Park S, Kim P-G, Park J (2007) Aquatic toxicity of acetaminophen, carbamazepine, cimetidine, diltiazem and six major sulfonamides, and their potential ecological risks in Korea. Environ Int 33(3):370-375. https://doi.org/10.1016/j.envint.2006.11.017

76. Korekar G, Kumar A, Ugale C (2020) Occurrence, fate, persistence and remediation of caffeine: A review. Environ Sci Pollut Res 27(28):34715-34733. https://doi.org/10.1007/s11356-019-06998-8

77. Kosma Cl, Lambropoulou DA, Albanis TA (2014) Investigation of PPCPs in wastewater treatment plants in Greece: Occurrence, removal and environmental risk assessment. Sci Total Environ 466467:421-438. https://doi.org/10.1016/j.scitotenv.2013.07.044

78. Krogh J, Lyons S, Lowe CJ (2017) Pharmaceuticals and Personal Care Products in Municipal Wastewater and the Marine Receiving Environment Near Victoria Canada. Frontiers in Marine Science, 0 . https://doi.org/10.3389/fmars.2017.00415

79. Kumar R, Sarmah AK, Padhye LP (2019) Fate of pharmaceuticals and personal care products in a wastewater treatment plant with parallel secondary wastewater treatment train. J Environ Manage 233:649-659. https://doi.org/10.1016/j.jenvman.2018.12.062

80. Küster A, Alder AC, Escher BI, Duis K, Fenner K, Garric J, Hutchinson TH, Lapen DR, Péry A, Römbke J, Snape J, Ternes T, Topp E, Wehrhan A, Knacker T (2010) Environmental risk assessment of human pharmaceuticals in the European Union: A case study with the $\beta$-blocker atenolol. Integr Environ Assess Manag 6(S1):514-523. https://doi.org/10.1897/IEAM_2009-050.1

81. Li S, He B, Wang J, Liu J, Hu X (2020) Risks of caffeine residues in the environment: Necessity for a targeted ecopharmacovigilance program. Chemosphere 243:125343. https://doi.org/10.1016/j.chemosphere.2019.125343

82. Li Y, Zhang X, Li W, Lu X, Liu B, Wang J (2012) The residues and environmental risks of multiple veterinary antibiotics in animal faeces. Environ Monit Assess 185(3):2211-2220. doi:10.1007/s10661-012-2702-1

83. Liu X, Liang C, Liu X, Zhao F, Han C (2020) Occurrence and human health risk assessment of pharmaceuticals and personal care products in real agricultural systems with long-term reclaimed wastewater irrigation in Beijing, China. Ecotoxicol Environ Saf 190:110022. https://doi.org/10.1016/j.ecoenv.2019.110022

84. Lolić A, Paíga P, Santos LHMLM, Ramos S, Correia M, Delerue-Matos C (2015) Assessment of nonsteroidal anti-inflammatory and analgesic pharmaceuticals in seawaters of North of Portugal: 
Occurrence and environmental risk. Sci Total Environ 508:240-250.

https://doi.org/10.1016/j.scitotenv.2014.11.097

85. Madikizela LM, Ncube S, Chimuka L (2018) Uptake of pharmaceuticals by plants grown under hydroponic conditions and natural occurring plant species: A review. Sci Total Environ 636:477-486. https://doi.org/10.1016/j.scitotenv.2018.04.297

86. Minguez, L., Pedelucq, J., Farcy, E., Ballandonne, C., Budzinski, H., \& Halm-Lemeille, M.-P. (2016). Toxicities of 48 pharmaceuticals and their freshwater and marine environmental assessment in northwestern France. Environmental Science and Pollution Research, 23(6), 4992-5001. https://doi.org/10.1007/s11356-014-3662-5

87. MMA. Ministério do Meio Ambiente. Resoluções Conama. Em linha: < www2.mma.gov.br/port/conama/>. Acesso em 2021.

88. Moore MT, Greenway SL, Farris JL, Guerra B (2008) Assessing Caffeine as an Emerging Environmental Concern Using Conventional Approaches. Arch Environ Contam Toxicol 54(1):31-35. https://doi.org/10.1007/s00244-007-9059-4

89. Narvaez V, Jimenez JF (2012) C. Pharmacuetical Product in the environment: sources, efdects and risks. Vitae [online]. 2012, vol.19, n.1, pp.93-108. ISSN 0121-4004. (http://www.scielo.org.co/pdf/vitae/v19n1/v19n1a10.pdf)

90. Ng B, Quinete N, Maldonado S, Lugo K, Purrinos J, Briceño H, Gardinali P (2021) Understanding the occurrence and distribution of emerging pollutants and endocrine disruptors in sensitive coastal South Florida Ecosystems. Sci Total Environ 757:143720. https://doi.org/10.1016/j.scitotenv.2020.143720

91. Nunes B, Antunes SC, Santos J, Martins L, Castro BB (2014) Toxic potential of paracetamol to freshwater organisms: A headache to environmental regulators? Ecotoxicol Environ Saf 107:178185. https://doi.org/10.1016/j.ecoenv.2014.05.027

92. Nunes B, Daniel D, Canelas GG, Barros J, Correia AT (2020) Toxic effects of environmentally realistic concentrations of diclofenac in organisms from two distinct trophic levels, Hediste diversicolor and Solea senegalensis. Comp Biochem Physiol C: Toxicol Pharmacol 231:108722. https://doi.org/10.1016/j.cbpc.2020.108722

93. Ojemaye CY, Petrik L ([s.d.]). Pharmaceuticals and Personal Care Products in the Marine Environment Around False Bay, Cape Town, South Africa: Occurrence and Risk-Assessment Study. Environmental Toxicology and Chemistry, n/a(n/a). https://doi.org/10.1002/etc.5053

94. Ortiz de García S, Pinto Pinto G, García Encina P, Mata I, R (2013) Consumption and occurrence of pharmaceutical and personal care products in the aquatic environment in Spain. Sci Total Environ 444:451-465. https://doi.org/10.1016/j.scitotenv.2012.11.057

95. Osorio V, Larrañaga A, Aceña J, Pérez S, Barceló D (2016) Concentration and risk of pharmaceuticals in freshwater systems are related to the population density and the livestock units in Iberian Rivers. Sci Total Environ 540:267-277. https://doi.org/10.1016/j.scitotenv.2015.06.143 
96. Overturf MD, Anderson JC, Pandelides Z, Beyger L, Holdway DA (2015) Pharmaceuticals and personal care products: A critical review of the impacts on fish reproduction. Crit Rev Toxicol. 2015 Jul;45(6):469-91. doi: 10.3109/10408444.2015.1038499. Epub 2015 May 6. PMID: 25945515. Em linha: Disponível em:https://www.tandfonline.com/doi/abs/10.3109/10408444.2015.1038499>

97. Peña-Guzmán C, Ulloa-Sánchez S, Mora K, Helena-Bustos R, Lopez-Barrera E, Alvarez J, RodriguezPinzón M (2019) Emerging pollutants in the urban water cycle in Latin America: A review of the current literature. J Environ Manage 237:408-423. https://doi.org/10.1016/j.jenvman.2019.02.100

98. Quadra GR, Oliveira de Souza H, Costa RdS, Fernandez MAS (2017) Do pharmaceuticals reach and affect the aquatic ecosystems in Brazil? A critical review of current studies in a developing country. Environ Sci Pollut Res 24:1200-1218. https://doi.org/10.1007/s11356-016-7789-4

99. Pereira AL, de Vasconcelos Barros RT, Pereira SR (2017) Pharmacopollution and Household Waste Medicine (HWM): how reverse logistics is environmentally important to Brazil. Environ Sci Pollut Res 24:24061-24075. https://doi.org/10.1007/s11356-017-0097-9

100. Pires A, Almeida Â, Correia J, Calisto V, Schneider RJ, Esteves VI, Freitas R (2016) Long-term exposure to caffeine and carbamazepine: impacts on the regenerative capacity of the polychaete Diopatra neapolitana. Chemosphere 146:565-573. https://doi.org/ 10.1016/j.chemosphere.2015.12.035

101. Rigueto CVT, Nazari MT, De Souza CF, Cadore JS, Brião VB, Piccin JS (2020) Alternative techniques for caffeine removal from wastewater: An overview of opportunities and challenges. Journal of Water Process Engineering 35:101231. https://doi.org/10.1016/j.jwpe.2020.101231

102. Roveri V, Guimarães LL, Toma W, Correia AT (2020a) Occurrence and ecological risk assessment of pharmaceuticals and cocaine in a beach area of Guarujá, São Paulo State, Brazil, under the influence of urban surface runoff. Environ Sci Pollut Res 27(36):45063-45075.

https://doi.org/10.1007/s11356-020-10316-y

103. Roveri V, Guimarães LL, Toma W, Correia AT (2021a) Occurrence and risk assessment of pharmaceuticals and cocaine around the coastal submarine sewage outfall in Guarujá, São Paulo State, Brazil. Environ Sci Pollut Res 28(9):11384-11400. https://doi.org/10.1007/s11356-02011320-y

104. Roveri V, Guimarães LL, Toma W, Correia AT (2021b) Occurrence and ecological risk assessment of pharmaceuticals and cocaine in the urban drainage channels of Santos beaches (São Paulo, Brazil): a neglected, but sensitive issue. Environ Sci Pollut Res. doi:10.1007/s11356-021-15249-8

105. Santos-Silva TG, Montagner CC, Martinez CBR (2018) Evaluation of caffeine effects on biochemical and genotoxic biomarkers in the neotropical freshwater teleost Prochilodus lineatus. Environ Toxicol Pharmacol 58:237-242. https://doi.org/10.1016/j.etap.2018.02.002

106. Sathishkumar P, Meena RAA, Palanisami T, Ashokkumar V, Palvannan T, Gu FL (2020) Occurrence, interactive effects and ecological risk of diclofenac in environmental compartments and biota-A review. Sci Total Environ 698:134057. https://doi.org/10.1016/j.scitotenv.2019.134057

107. SDE - Secretaria do Estado do Desenvolvimento Econômico Sustentável. Recursos hídricos de Santa Catarina. Em linha: Disponível em: 
http://www.aguas.sc.gov.br/jsmallfib_top/DHRI/bacias_hidrograficas/bacias_hidrograficas_sc.pdf. Acesso em 2020

108. SEBRAE. Serviço Brasileiro de Apoio às Micro e Pequenas Empresas. Santa Catarina em números. Florianópolis, 2013. Em linha: Disponível em. Acesso em fevereiro de 2021.

109. Shahriar A, Tan J, Sharma P, Hanigan D, Verburg P, Pagilla K, Yang Y (2021) Modeling the fate and human health impacts of pharmaceuticals and personal care products in reclaimed wastewater irrigation for agriculture. Environ Pollut 276:116532. https://doi.org/10.1016/j.envpol.2021.116532

110. Shihomatzu HM, Brasil (2015) IPEN/USP. https://doi.org/10.11606/T.85.2015.tde-28042015-095207

111. Sirbu DM, Curseu D, Popa M, Cadariu AA, Moldovan Z ([s.d.]). Environmental Risks of Pharmaceuticals and Personal Care Products in Water. Tenth International Water Technology Conference, IWTC10 2006, Alexandria, Egypt 1151

112. Souza AdeM, Pereira RA, Yokoo EM, Levy RB, Sichieri R (2013) Alimentos mais consumidos no Brasil: Inquérito Nacional de Alimentação 2008-2009. Revista de Saúde Pública 47:190s-199s. https://doi.org/10.1590/S0034-89102013000700005

113. Stewart M, Olsen G, Hickey CW, Ferreira B, Jelić A, Petrović M, Barcelo D (2014) A survey of emerging contaminants in the estuarine receiving environment around Auckland, New Zealand. Sci Total Environ 468-469:202-210. https://doi.org/10.1016/j.scitotenv.2013.08.039

114. Sui Q, Cao X, Lu S, Zhao W, Qiu Z, Yu G (2015) Occurrence, sources and fate of pharmaceuticals and personal care products in the groundwater: A review. Emerging Contaminants 1(1):14-24. https://doi.org/10.1016/j.emcon.2015.07.001

115. Sun Q, Li M, Ma C, Chen X, Xie X, Yu C-P (2016) Seasonal and spatial variations of PPCP occurrence, removal and mass loading in three wastewater treatment plants located in different urbanization areas in Xiamen, China. Environ Pollut 208:371-381. https://doi.org/10.1016/j.envpol.2015.10.003

116. Tarpani RRicardoZ, Azapagic A (2018) Life cycle environmental impacts of advanced wastewater treatment techniques for removal of pharmaceuticals and personal care products (PPCPs), Journal of Environmental Management, Volume 215, 2018, Pages 258-272, ISSN 0301-4797, https://doi.org/10.1016/j.jenvman.2018.03.047. (https://www.sciencedirect.com/science/article/pii/S0301479718302743)

117. Thomaidi VS, Stasinakis AS, Borova VL, Thomaidis NS (2015) Is there a risk for the aquatic environment due to the existence of emerging organic contaminants in treated domestic wastewater? Greece as a case-study. J Hazard Mater 283:740-747. https://doi.org/10.1016/j.jhazmat.2014.10.023

118. Turek M, Różycka-Sokołowska E, Owsianik K, Marciniak B, Bałczewski P (2020) Modification of the Microtox $\circledast$ Basic Solid Phase Test: A new application for the ecotoxicological studies on poorly soluble antihypertensive drugs. J Hazard Mater 399:122839. https://doi.org/10.1016/j.jhazmat.2020.122839

119. USEPA - United States Environmental Protection Agency (2017) Ecological Structure-Activity Relationship Model (ECOSAR) Class Program. MS-Windows Version 2.0. 
https://www.epa.gov/tsca732 screening-tools/ecological-structure-activity-relationshipsecosarcpredictive-model

120. USEPA - United States Environmental Protection Agency (2019) ECOTOX User Guide: Ecotoxicology Database System, Version 4.0. http://www.epa.gov/ecotox/

121. van den Brandhof E-J, Montforts M (2010) Fish embryo toxicity of carbamazepine, diclofenac and metoprolol. Ecotoxicol Environ Saf 73(8):1862-1866. https://doi.org/10.1016/j.ecoenv.2010.08.031

122. Vieno N, Tuhkanen $T$, Kronberg $L$ (2007) Elimination of pharmaceuticals in sewage treatment plants in Finland. Water Res 41(5):1001-1012. https://doi.org/10.1016/j.watres.2006.12.017

123. Wang H, Xi H, Xu L, Jin M, Zhao W, Liu H (2021) Ecotoxicological effects, environmental fate and risks of pharmaceutical and personal care products in the water environment: A review. Sci Total Environ 788:147819. https://doi.org/10.1016/j.scitotenv.2021.147819

124. Wang J, Wang S (2016) Removal of pharmaceuticals and personal care products (PPCPs) from wastewater: A review. J Environ Manage 182:620-640. https://doi.org/10.1016/j.jenvman.2016.07.049

125. Watanabe H, Tamura I, Abe R, Takanobu H, Nakamura A, Suzuki T, Hirose A, Nishimura T, Tatarazako $N$ (2016) Chronic toxicity of an environmentally relevant mixture of pharmaceuticals to three aquatic organisms (alga, daphnid, and fish). Environ Toxicol Chem 35(4):996-1006. https://doi.org/10.1002/etc.3285

126. WHO, World Health Organization. Promoting rational use of medicines (who.int), Becker W, Ibáñez R, Lumbaque MCuervo, Wilde E, da Rosa MLF, Hernández T, Sirtori C (2020) Investigation of pharmaceuticals and their metabolites in Brazilian hospital wastewater by LC-QTOF MS screening combined with a preliminary exposure and in silico risk assessment. Science of The Total Environment, 699, 134218. https://doi.org/10.1016/j.scitotenv.2019.134218

127. Wilkinson J, Hooda PS, Barker J, Barton S, Swinden J (2017) Occurrence, fate and transformation of emerging contaminants in water: An overarching review of the field. Environ Pollut 231:954-970. https://doi.org/10.1016/j.envpol.2017.08.032

128. Wille K, Kiebooms JAL, Claessens M, Rappé K, Vanden Bussche J, Noppe H, Vanhaecke L (2011) Development of analytical strategies using U-HPLC-MS/MS and LC-ToF-MS for the quantification of micropollutants in marine organisms. Anal Bioanal Chem 400(5):1459-1472. https://doi.org/10.1007/s00216-011-4878-6

129. Wille K, Noppe H, Verheyden K, Vanden Bussche J, De Wulf E, Van Caeter P, Vanhaecke L (2010) Validation and application of an LC-MS/MS method for the simultaneous quantification of 13 pharmaceuticals in seawater. Anal Bioanal Chem 397(5):1797-1808. doi:10.1007/s00216-010-3702z

130. Winter MJ, Lillicrap AD, Caunter JE, Schaffner C, Alder AC, Ramil M, Ternes TA, Giltrow E, Sumpter JP, Hutchinson TH (2008) Defining the chronic impacts of atenolol on embryo-larval development and reproduction in the fathead minnow (Pimephales promelas). Aquat Toxicol 86(3):361-369. https://doi.org/10.1016/j.aquatox.2007.11.017 
131. Wu X, Dodgen LK, Conkle JL, Gan J (2015) Plant uptake of pharmaceutical and personal care products from recycled water and biosolids: A review. Sci Total Environ 536:655-666. https://doi.org/10.1016/j.scitotenv.2015.07.129

132. Yang L, Zhou Y, Shi B, Meng J, He B, Yang H, Yoon SJ, Kim T, Kwon B-O, Khim JS, Wang T (2020) Anthropogenic impacts on the contamination of pharmaceuticals and personal care products (PPCPs) in the coastal environments of the Yellow and Bohai seas. Environ Int 135:105306. https://doi.org/10.1016/j.envint.2019.105306

133. Yang X, Flowers RC, Weinberg HS, Singer PC (2011) Occurrence and removal of pharmaceuticals and personal care products (PPCPs) in an advanced wastewater reclamation plant. Water Res 45(16):5218-5228. https://doi.org/10.1016/j.watres.2011.07.026

134. Yang Y, Ok YS, Kim K-H, Kwon EE, Tsang YF (2017) Occurrences and removal of pharmaceuticals and personal care products (PPCPs) in drinking water and water/sewage treatment plants: A review. Sci Total Environ 596-597:303-320. https://doi.org/10.1016/j.scitotenv.2017.04.102

135. Yin L, Wang B, Yuan H, Deng S, Huang J, Wang Y, Yu G (2017) Pay special attention to the transformation products of PPCPs in environment. Emerging Contaminants 3(2):69-75. https://doi.org/10.1016/j.emcon.2017.04.001

136. Yuan X, Hu J, Li S, Yu M (2020) Occurrence, fate, and mass balance of selected pharmaceutical and personal care products (PPCPs) in an urbanized river. Environ Pollut 266:115340. https://doi.org/10.1016/j.envpol.2020.115340

137. Zhou Y, Meng J, Zhang M, Chen S, He B, Zhao H, Li Q, Zhang S, Wang T (2019) Which type of pollutants need to be controlled with priority in wastewater treatment plants: Traditional or emerging pollutants? Environ Int 131:104982. https://doi.org/10.1016/j.envint.2019.104982

\section{Figures}




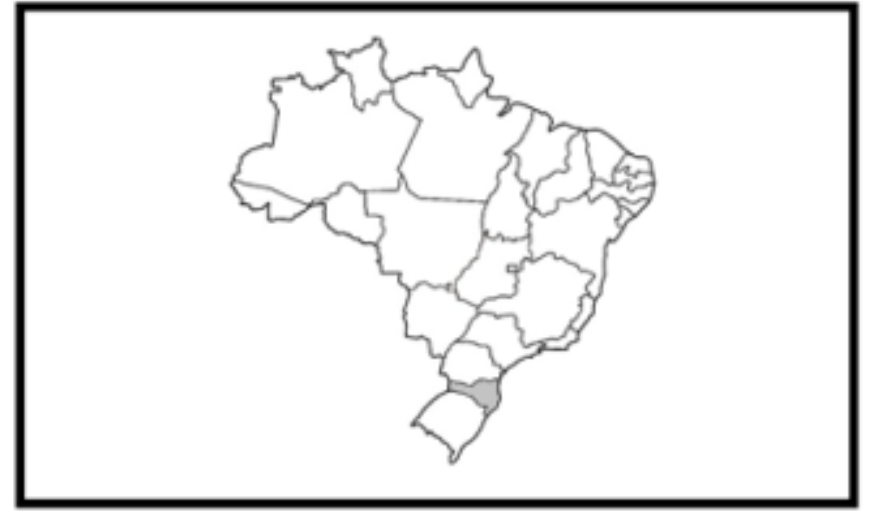

(B)

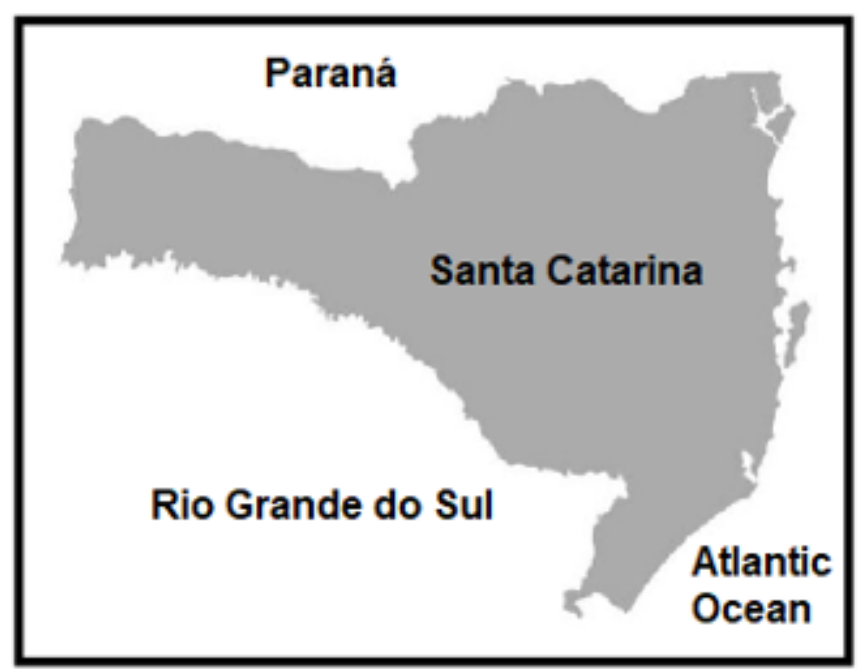

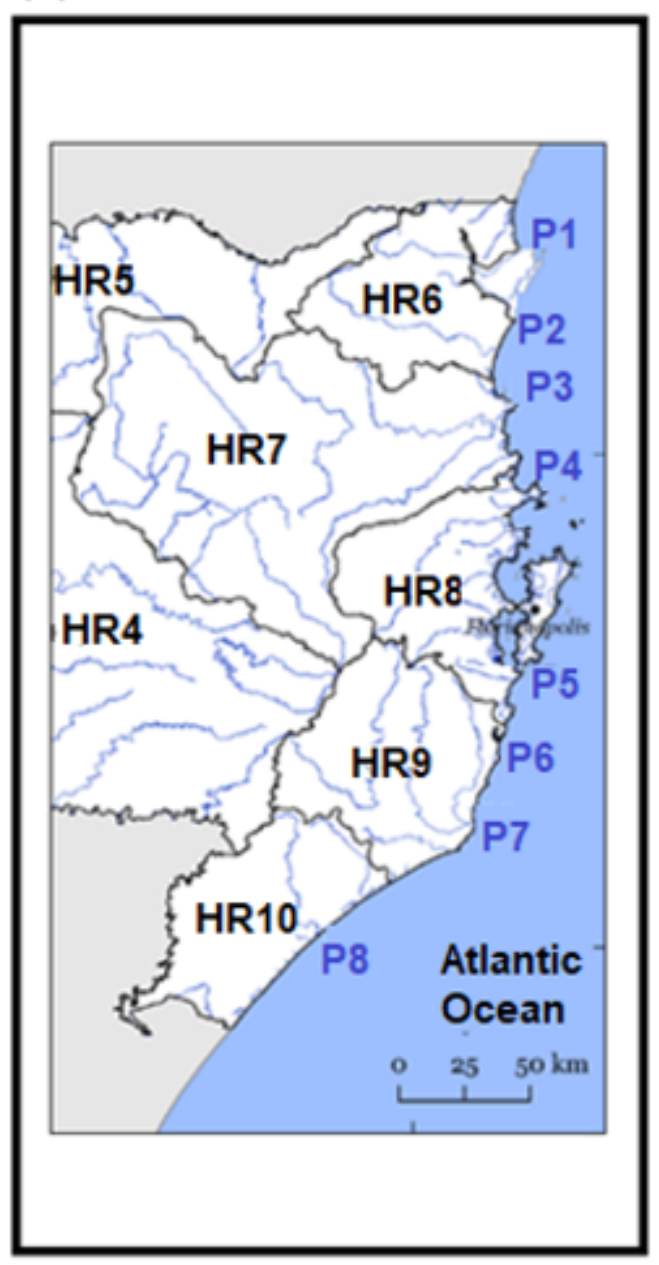

Figure 1

Map of Brazil with the Santa Catarina State in grey colour (A). Magnification of Santa Catarina showing the neighbour states, Paraná and Rio Grande do Sul (B). Santa Catarina coastal area, showing the hydrographic regions (HR) that belong to the Sistema da Vertente Atlântica (SVA), and identification of the study sampling points: São Francisco do Sul (P1), Balneário Barra do Sul (P2), Penha (P3), Enseada do Brito, Palhoça (P4), Baia de Zimbros, Porto Belo, (P5), Imbituba (P6), Laguna (P7) and Balneário Rincão (P8). For more details, see M\&M. 

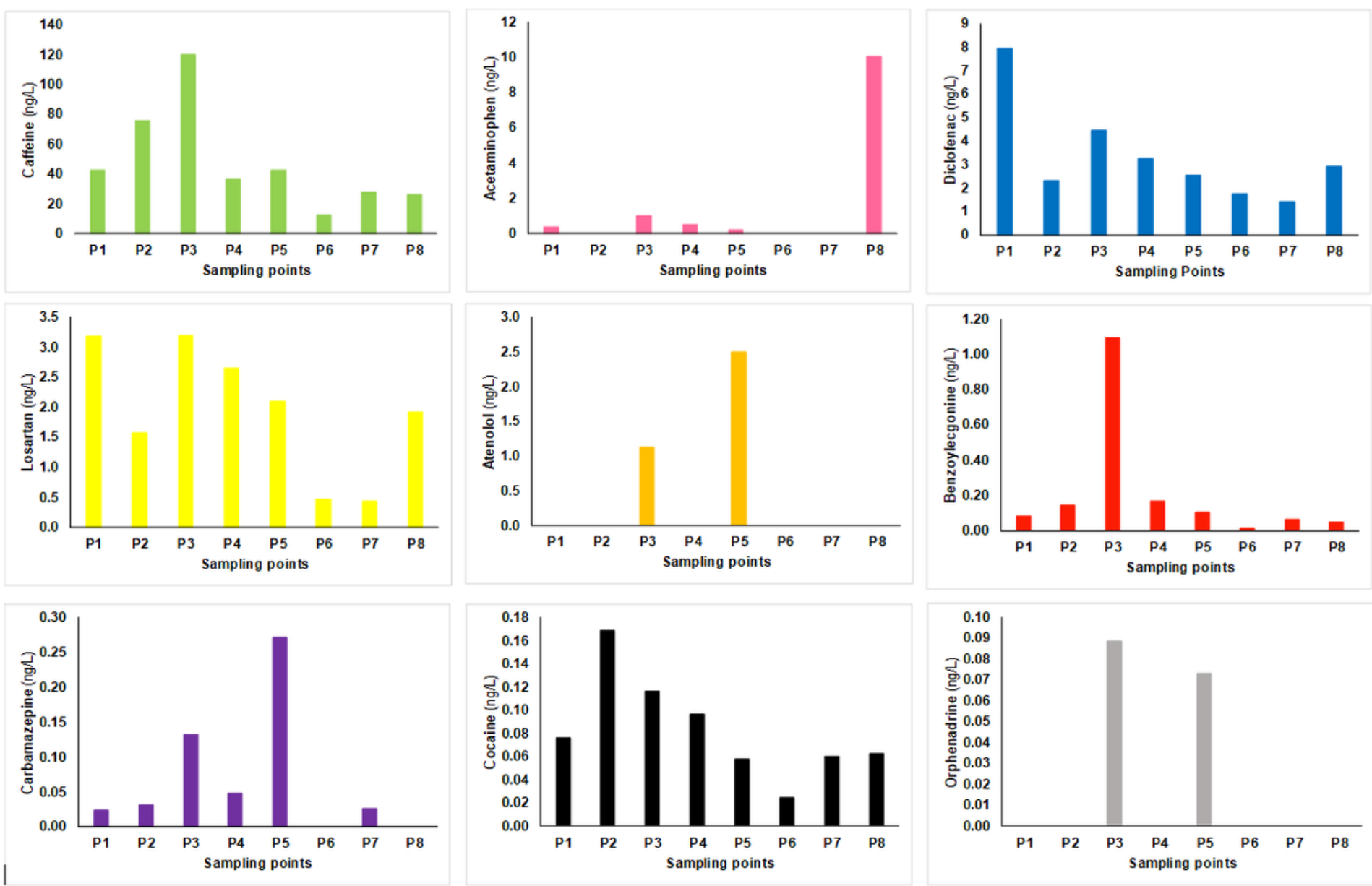

Figure 2

Environmental measured concentration of the various PPCPs (ng/L) at each sampling point. Empty cells represent values below the detection limit (<LOD). 


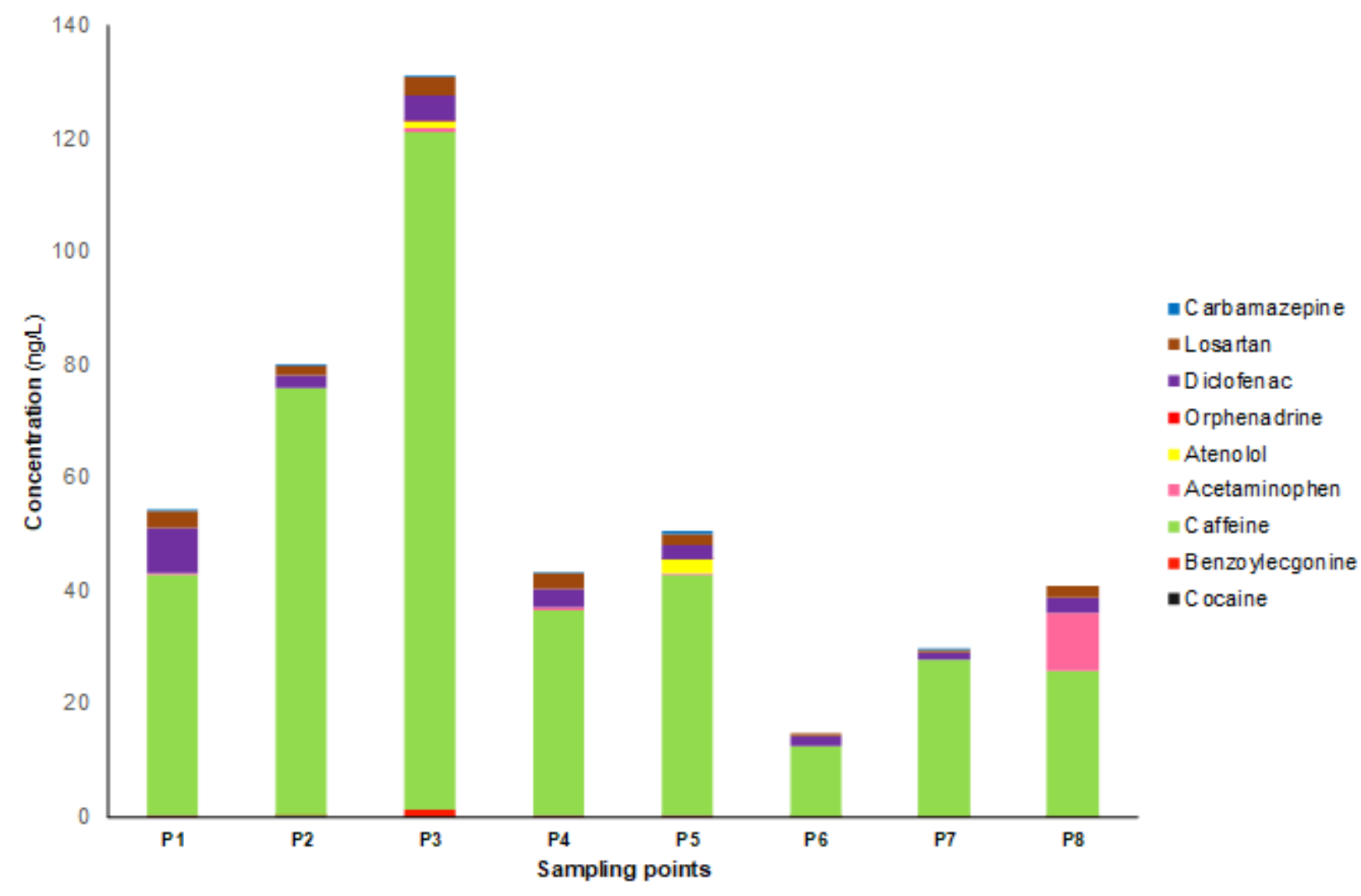

Figure 3

Environmental measured concentrations of the various PPCPs $(\mathrm{ng} / \mathrm{L})$ at each sampling point located in the coastal marine waters of Santa Catarina, Brazil.

\section{Supplementary Files}

This is a list of supplementary files associated with this preprint. Click to download.

- Article1SupplementaryMaterialPisettaetal.docx 